\title{
Review \\ Current Progress in Vascular Engineering and Its Clinical Applications
}

\author{
Hatem Jouda ${ }^{1}$, Luis Larrea Murillo ${ }^{2}$ and Tao Wang ${ }^{2, *}$ \\ 1 Manchester Medical School, Faculty of Biology, Medicine and Health, University of Manchester, \\ Manchester M13 9PL, UK; hatem.jouda@student.manchester.ac.uk \\ 2 School of Biological Sciences, Faculty of Biology, Medicine and Health, University of Manchester, \\ Manchester M13 9PL, UK; luis.larrea@postgrad.manchester.ac.uk \\ * Correspondence: tao.wang@manchester.ac.uk; Tel.: +44-161-275-1508
}

Citation: Jouda, H.; Larrea Murillo, L.; Wang, T. Current Progress in Vascular Engineering and Its Clinical Applications. Cells 2022, 11, 493. https://doi.org/10.3390/ cells11030493

Academic Editors: Friedrich Jung Michael Raghunath, Anna Blocki and Cord Brakebusch

Received: 9 January 2022

Accepted: 29 January 2022

Published: 31 January 2022

Publisher's Note: MDPI stays neutral with regard to jurisdictional claims in published maps and institutional affiliations.

Copyright: (C) 2022 by the authors. Licensee MDPI, Basel, Switzerland. This article is an open access article distributed under the terms and conditions of the Creative Commons Attribution (CC BY) license (https:// creativecommons.org/licenses/by/ $4.0 /)$.

\begin{abstract}
Coronary heart disease (CHD) is caused by narrowing or blockage of coronary arteries due to atherosclerosis. Coronary artery bypass grafting (CABG) is widely used for the treatment of severe CHD cases. Although autologous vessels are a preferred choice, healthy autologous vessels are not always available; hence there is a demand for tissue engineered vascular grafts (TEVGs) to be used as alternatives. However, producing clinical grade implantable TEVGs that could healthily survive in the host with long-term patency is still a great challenge. There are additional difficulties in producing small diameter $(<6 \mathrm{~mm})$ vascular conduits. As a result, there have not been TEVGs that are commercially available. Properties of vascular scaffolds such as tensile strength, thrombogenicity and immunogenicity are key factors that determine the biocompatibility of TEVGs. The source of vascular cells employed to produce TEVGs is a limiting factor for large-scale productions. Advanced technologies including the combined use of natural and biodegradable synthetic materials for scaffolds in conjunction with the use of mesenchyme stem cells or induced pluripotent stem cells (iPSCs) provide promising solutions for vascular tissue engineering. The aim of this review is to provide an update on various aspects in this field and the current status of TEVG clinical applications.
\end{abstract}

Keywords: vascular tissue engineering; ischemic heart disease; tissue engineered vascular grafts; induced pluripotent stem cells; mesenchyme stem cells

\section{Background}

Healthy blood vessels are integral to body function. They provide tissues with nutrients and oxygen, as well as remove waste products such as carbon dioxide and metabolites. With the exception of capillaries, all blood vessels are composed of three main cellular layers: the tunica intima, tunica media and tunica adventitia (Figure 1) [1,2]. The major cell types that compose these layers are endothelial cells (ECs) for the intima, vascular smooth muscle cells (VSMCs) for the media and fibroblasts for the adventitia. There are structural differences among different types of vessels, e.g., arteries versus veins, small resistance arteries versus large conduit arteries, in addition to different compositions of the extracellular matrix (ECM), which support and regulate specific functions of blood vessels $[3,4]$. Certain risk factors induce pathological changes in blood vessels, leading to common cardiovascular conditions. For example, endothelial damages caused by smoking, obesity, and aging lead to atherosclerosis, which can ultimately manifest into coronary heart disease (CHD) or ischaemic heart disease (IHD) [5].

Despite efforts to reduce the occurrence of CHD through healthy living campaigns and primary prevention medications, it remains the leading cause of mortality worldwide. Statistically, the worldwide mortality of CHD is predicted to rise to a staggering figure of 23.3 million by 2030 [6]. Current revascularisation therapies are mainly coronary angioplasty (followed by stenting) or coronary artery bypass grafting (CABG), aiming to open 
up or replace the occluded vessels. The gold standard vessel grafts with a small diameter (under $6 \mathrm{~mm}$ ) to be used in CABG surgeries are autologous, namely the saphenous vein or internal thoracic artery. The internal thoracic artery is the most effective conduit, with patency rates between $85-95 \%$ over 7 to 10 years $[7,8]$. The saphenous vein is the best with regard to ease of harvesting, but more liable to graft failure down the line [9]. However, the healthy autograft vessels used for CABG can be in short supply in some patients. It is estimated that $20-30 \%$ of patients who require a CABG surgery do not have suitable autologous vessels to be used as grafts [10]. Factors damaging vessel quality include comorbidities such as diabetes, as well as long-standing peripheral artery disease. This creates a huge demand for alternative sources of vascular conduits-namely tissue engineered vascular grafts (TEVGs) [11].

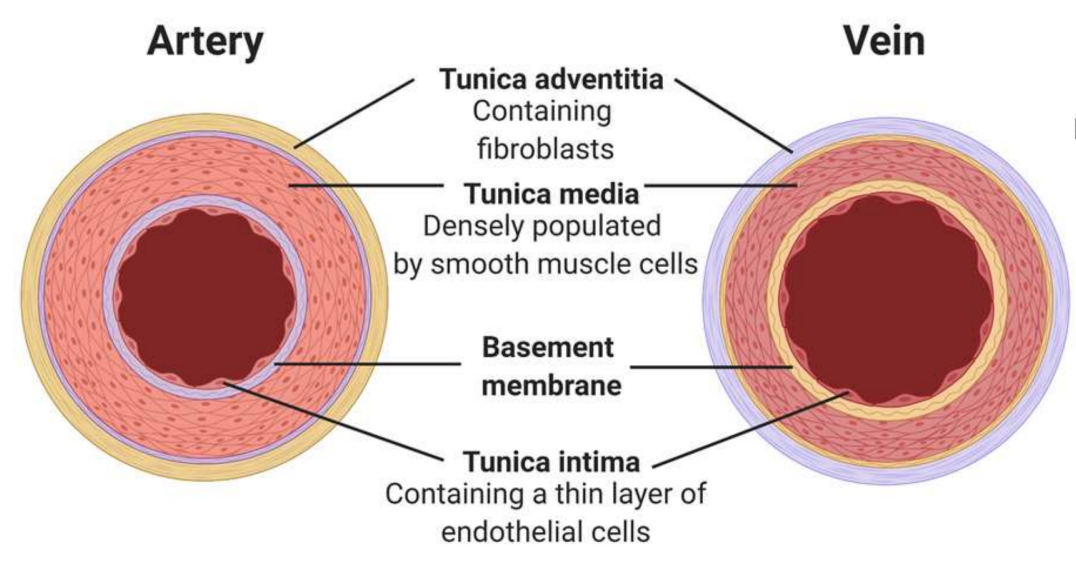

\section{Capillary}

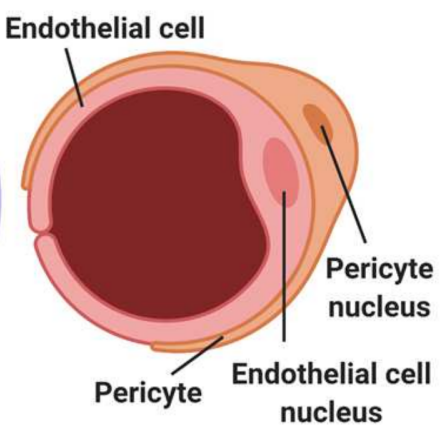

Figure 1. Structure of blood vessels. Diagram shows compositions of the three main types. From left to right: artery, vein and capillary. (Created with BioRender.com, accessed on 8 January 2022).

Although engineered vascular grafts have shown promising long-term outcomes when replacing large- and medium-sized arteries, there have been poor patency rates associated with small-diameter vessels such as coronary arteries [10]. Hence there is a clear need to improve the quality and biocompatibility of small diameter vascular conduits to meet the clinical demand and provide alternative grafts for patients. Fortunately, recent technological advances have provided the possibly of producing long lasting grafts to address the clinical need. This has been achieved via different manufacturing methods. These include scaffold-free methods which use cells to produce their own matrix, or cell sheets that can then be assembled into conduits using a mandrel or rod, as well as more traditional methods that use polymer based or decellularised tissue scaffolds that can be laden with cells to fabricate vessel-like conduits (Figure 2) [12-15]. This report will explore the advancements and challenges associated with vascular engineering, with a focus on small diameter vessels. 

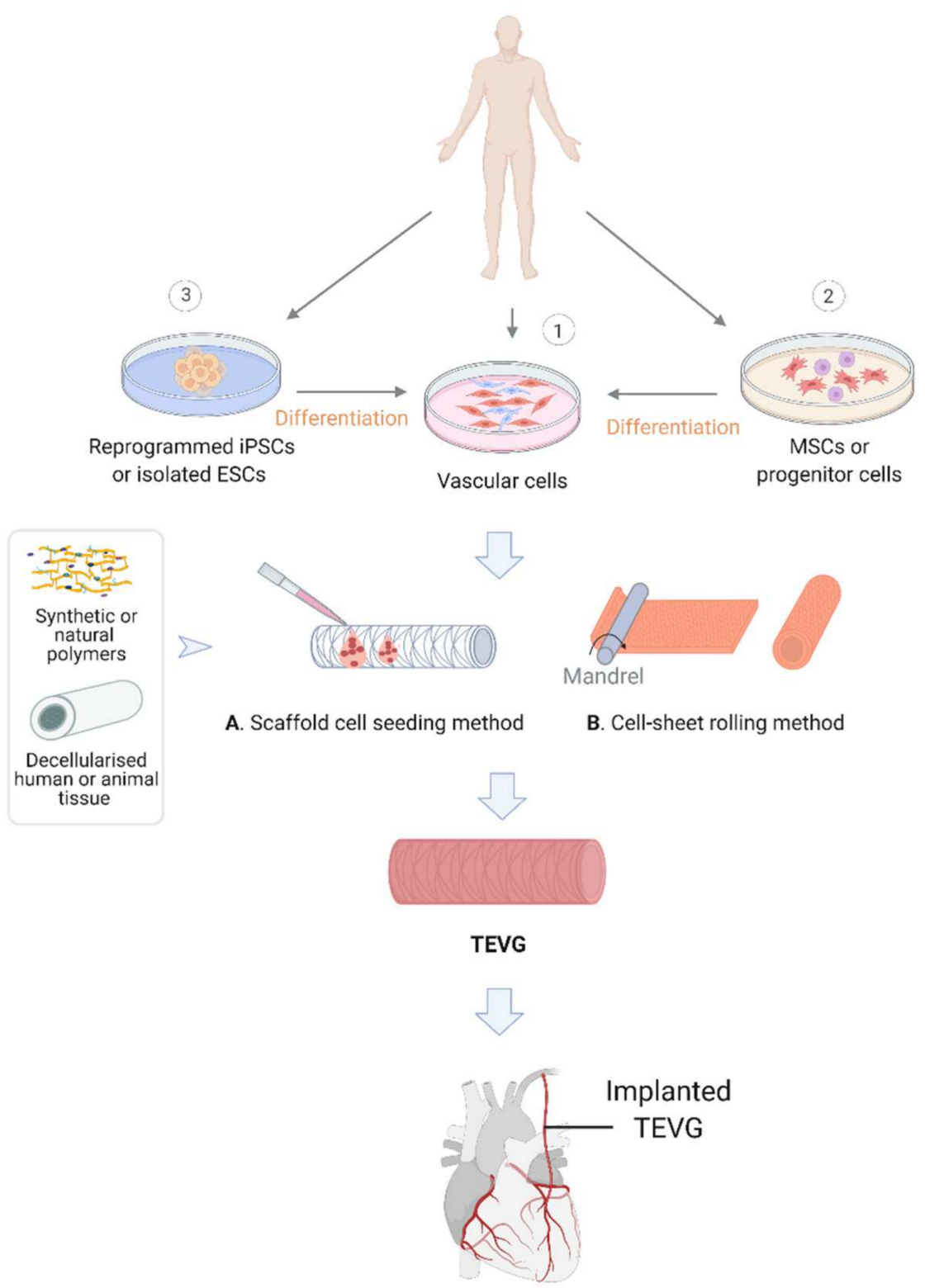

Figure 2. Vascular tissue engineering. Vascular cells can either be harvested from donors (1) or differentiated from mesenchymal stem cells (MSCs) or progenitor cells isolated from donors (2). Vascular cells can also be differentiated from pluripotent cells such as isolated embryonic stem cells (ESCs) or induced pluripotent stem cells (iPSCs) that were reprogrammed from somatic cells (e.g., dermal fibroblasts or blood monocytes) of the donor (3). A-Scaffold-based tissue-engineering: Vascular SMCs and ECs are seeded onto scaffold materials that can either be synthetic polymers or decellularised vascular scaffolds. B-Scaffold-free vascular engineering: TEVG produced via vascular cell bioprinting or rolling sheets of autologous vascular cells into a tubular structure. The constructs from A or B are then cultured ideally in a bioreactor to develop suitable properties of a TEVG for clinical implantation such as coronary artery bypass grafting. (Created with Biorender.com, accessed on 8 January 2022).

\section{Design Requirements for TEVGs}

For a successful TEVG, it is important to identify the key design requirements [16]. Since the grafts are to be implanted to support blood flow in vivo, certain mechanical properties are required to prevent leakage, rupture or aneurysm formation [17]. Firstly, the graft should have adequate burst pressure and compliance properties that can handle the physiological blood flow at the implantation site. Secondly, the grafts must be bio- 
compatible to the host tissue and survive in the in vivo environment by having minimum immunogenicities to minimise inflammation and avoid rejection. Moreover, grafts are required to integrate with the anastomosing vessels in vivo and promote angiogenesis at the implantation site [18]. This means they require the capability of self-repairing and remodeling to avoid graft failure and provide longevity. Specific to small diameter vessels, the lumen must possess an endothelial layer to prevent thrombus formation [19]. Figure 3 summarised key factors to be considered when choosing the materials, cell types and manufacturing processes to produce an ideal TEVG.

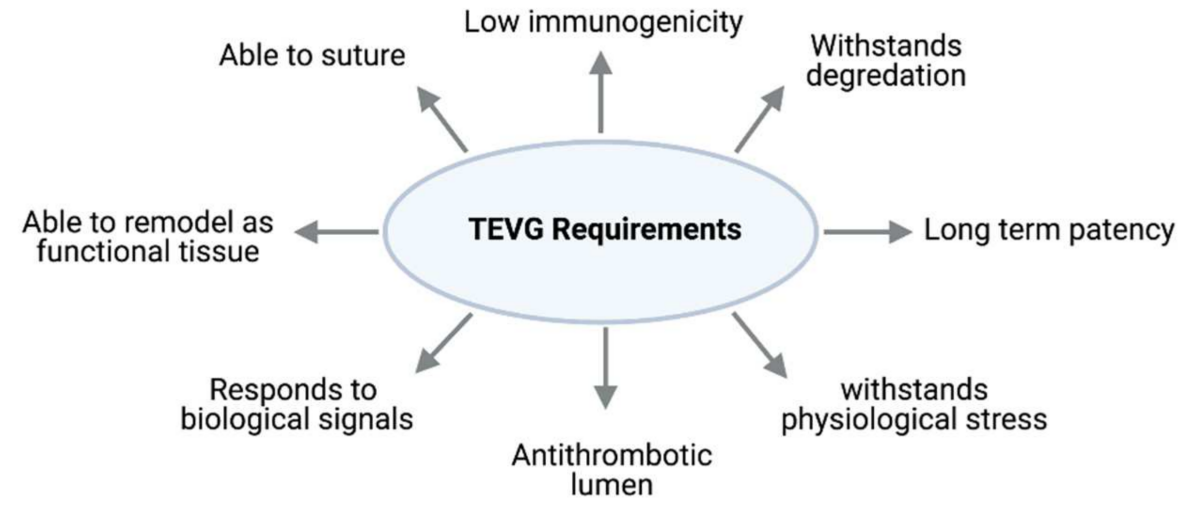

Figure 3. Key factors to be considered for an ideal TEVG.

\section{Scaffolds for Vascular Tissue Engineering}

Functions of blood vessels are supported by the ECM that also varies in composition and architecture according to vessel types. The ECM not only provides support and anchorage for cells which are critical for cell survival, but also regulates cell behaviours such as directing cell proliferation and migration, as well as sequestering growth factors [4]. These properties are integral to the biological adaptation of TEVGs and their response to physiological signals. Hence, engineered vascular conduits are required to possess a medium that has similar functions as the ECM. One way to provide this is through a scaffold, which acts as a matrix for cells to organise into 3D structures. Therefore, an ideal scaffold should replicate the functionalities of the ECM to support the biological and mechanical properties of blood vessels for in vivo applications [20]. The scaffold should be non-thrombogenic and non-immunogenic, and have a suitable elasticity and pore size to accommodate cells growing within it. Moreover, scaffolds need to support cell growth, differentiation and tissue regeneration processes. Furthermore, an ideal scaffold is biodegradable and allows the implanted cells to integrate with the native vessels in vivo [21,22]. There are a wide variety of materials that can be used as scaffolds, ranging from natural products to synthetic materials, or a mixture of both.

\subsection{Natural Polymers}

Natural polymers offer a potential source for scaffold materials mainly due to their biocompatibility [23]. One such popular polymer is collagen, which is the most abundant protein in the ECM and is required for both weight-bearing and supporting cell function [24]. The collagen possesses a low antigenicity and thus reduces the risk of immune responses. Collagen, among other natural polymers such as elastin and fibrin, can be extracted from animal sources such as bovine tendons or porcine skin, making it widely available and cost effective [25]. However, a drawback of these sources is the batch-to-batch variability and potential pathogenic contamination [19]. In addition, although studies have shown success in venous systems, collagen-based scaffolds could not cope well with the pressure of the arterial system [24,26]. Moreover, there are ethical considerations when harvesting tissues from animals. This has led to the exploration of synthetic polymers to obtain alternative sources of ECM proteins. 


\subsection{Synthetic Polymers}

To address the mechanical shortcomings of natural polymers, vascular engineering moved towards using biodegradable synthetic polymers for scaffolding materials. Polyglycolic acid (PGA), polylactic acid (PLA) and polycaprolactone (PCL) are three of the most commonly used synthetic polymers [27]. These synthetic polymers are advantageous for their mechanical properties that can be tailored to meet the clinical needs in terms of degradation rate, elasticity and compliance. Moreover, these materials are cheap, readily available, and free of ethical issues that would arise from using natural polymers from animals [28]. An initial study showed that vessels engineered with PGA as a scaffold yielded strong grafts with rupture strengths exceeding that of the saphenous vein [22]. However, disadvantages of these materials involve their biological performance (Table 1). Breakdown products can also induce an inflammatory response and VSMC de-differentiation $[29,30]$. Although surface modifications can be made to improve biocompatibility issues, the bioactivity of the breakdown products should be more thoroughly investigated to ensure long-term safety of the scaffold [31,32]. Synthetic scaffolds can be blended or conjugated with natural polymers to improve biocompatibility $[33,34]$. Such strategy could generate well-rounded hybrid scaffolds to achieve overall adequacy with regard to mechanical properties and biocompatibility. Nevertheless, such hybrid scaffolds could still possess some of the limitations carried over from the original materials [35,36].

Table 1. Advantages and disadvantages of different scaffold techniques in the production of TEVGs.

\begin{tabular}{|c|c|c|c|}
\hline Vessel Type & Advantages & Disadvantages & References \\
\hline Natural Scaffolds & $\begin{array}{l}\text { Lack of immunogenicity } \\
\text { Cheaper \& readily } \\
\text { available source }\end{array}$ & $\begin{array}{l}\text { Weaker mechanical } \\
\text { properties } \\
\text { Risk of pathogenic } \\
\text { contamination } \\
\text { Batch to batch variability }\end{array}$ & [23-25] \\
\hline Synthetic Scaffolds & $\begin{array}{l}\text { Highly reproducible } \\
\text { Tailorable } \\
\text { mechanical properties }\end{array}$ & $\begin{array}{l}\text { Risk of immune rejection } \\
\text { and thrombogenicity }\end{array}$ & [28-30] \\
\hline Decellularised Matrix & $\begin{array}{l}\text { Preservation of ECM } \\
\text { components and } \\
\text { mechanical architecture }\end{array}$ & $\begin{array}{l}\text { More expensive } \\
\text { Risk of immune rejection if } \\
\text { not completely decellularised }\end{array}$ & {$[11,37]$} \\
\hline Self-assembled cell sheets & $\begin{array}{l}\text { Mimics native ECM } \\
\text { components } \\
\text { Lack of immunogenicity }\end{array}$ & $\begin{array}{l}\text { Long fabrication time } \\
\text { Mechanical properties vary } \\
\text { according to cell type }\end{array}$ & {$[38,39]$} \\
\hline
\end{tabular}

\subsection{Decellularised Scaffolds}

In parallel to the synthetic methods, decellularisation of native tissues has also been trialed to generate scaffolds. Animal tissues, such as arteries, are usually used for this purpose by being decellularised using chemical agents, enzymes or physical agitation (Figure 2). This method could maximally preserve the native ECM components and help maintain the mechanical properties of the tissue $[11,40]$. The decellularised scaffold is then used for the seeding of autologous or other sources of vascular cells in vitro. For example, cells from the descending aorta of fetal pigs were removed by trypsin, ribonuclease and desoxyribonuclease. Porcine aortic endothelial cells were then seeded onto the scaffold and demonstrated an excellent cell viability within scaffolds [40]. A recent study has seeded human pluripotent stem cell-derived vascular progenitors onto a decellularised rat vascular scaffold. By perfusion of the cell-laden scaffold with a defined medium containing PDGF-BB or VEGF-A165 and SB431542, the vascular progenitor cells were successfully differentiated into SMCs and ECs in situ. The recellularised scaffolds were then connected to the rat circulation, which is capable of supporting peripheral blood flow in vivo [41]. Another study differentiated xeno-free ECs from human induced pluripotent stem cells, which successfully endothelialised decellularised human umbilical cord arteries in a bioreactor with a circulatory culture medium [42]. Decellularised human umbilical artery patches were also used to accommodate human adipose stem cells for vascular 
engineering [43]. Although the approaches of decellularisation and recellularisation could potentially simplify the production of vascular scaffolds, there have been studies which suggest that this method does not pose any clear advantages compared to the synthetic alternatives. The decellurised scaffolds are more costly than the synthetics, and have the potential transmission of pathogens or elicit immunogenic response, leading to graft failure (Table 1) $[37,44]$. Treatment with glutaraldehyde can reduce the immune response of recipients to the xenogeneic tissues through its cross-linking function; however, this reagent has also been shown to induce inflammatory reactions that could contribute to graft failure $[45,46]$. One such mechanism is through increased calcification due to the addition of free aldehyde residues to the ECM scaffold, which is correlated with increased mechanical stress $[47,48]$.

\subsection{Scaffold-Free Techniques}

The potential complications of scaffolds on inflammation, thrombosis and rejection, and the challenges for the scaffold to mimic native ECM components for optimal cell-cell interactions and alignments have led to the emergence of scaffold-free techniques, mainly self-assembly (Figure 2) [49,50]. As pioneered by L'Heureux et al. [51], this approach involves producing sheets of autologous vascular cells, which are then shaped into a tubular structure. These are then conditioned in a bioreactor to allow the layers to fuse and produce their own ECM components $[48,51]$. This strategy has proved to be the first method to produce a TEVG with physiological mechanical properties without the presence of a scaffold. In a human clinical trial for haemodialysis, these grafts demonstrated a burst pressure around $2600 \mathrm{mmHg}$, well above that of the human saphenous vein [39]. It is important to note that haemodialysis applies supraphysiological flow rates to the graft, and also involves repeated needle punctures that apply additional stress on the graft. Therefore, the lifeline graft underwent extensive validation before the application [52]. Results from this study were promising, with seven out of nine patients (78\%) maintaining primary patency one month after implantation. Moreover, five out of remaining eight patients (60\%) maintained primary patency after six months. These results approach the objectives of the Dialysis Outcomes Quality Initiative of 76\% three months after implantation for native vein fistulas. The main reasons for graft failure in this study were thrombosis and aneurysm formation. On the downside, these grafts are expensive and have a long production time ranging from six to nine months [51]. However, recent studies by Jung et al. [50] and Saito et al. [53] have shown the feasibility of reducing production time to as low as 35 to 48 days using stem cells or progenitor cells [50,53].

\section{Cell Sources Used for Vascular Tissue Engineering}

\subsection{Autologous Vascular Cells}

ECs and VSMCs are of paramount importance to the structure and function of blood vessels, and thus equally important for TEVGs. A primary source of ECs and VSMCs is from the patients themselves, and these are also known as autologous vascular cells [16]. Although the advantage of this source is immune compatible, there are a number of drawbacks. Firstly, these cells are usually harvested through blood vessel biopsies, which is invasive and has a risk of donor site complications. Secondly there are limitations regarding the quantity of obtainable cells that usually have poor proliferative and regenerative capacities due to the advanced age of donors and the primary nature of the cells. Although the issue concerning proliferation was addressed through the expression of a human telomerase reverse transcriptase subunit, the age-associated senescence remains a challenge [54]. It is important to note that the use of genetic manipulation requires long-term follow-ups in vivo before being applied clinically. Furthermore, the process of harvesting and culturing primary cells is expensive and time consuming, thus presenting financial barriers. The challenges associated with using primary cells from patients led to efforts of acquiring ECs and VSMCs from stem cell-based approaches. 


\subsection{Embryonic Stem Cells}

In recent years, stem cells have emerged as a promising source for vascular engineering. The major advantage of stem cells is their ability of self-renewal and differentiation in accordance with the conditions applied. Broadly speaking, these come in two main categories: embryonic and adult stem cells (Figure 4) [55,56].

Embryonic stem cells (ESCs) are derived from embryos at the blastocyst stage and possess the ability to differentiate into cells from all three germ layers (ectoderm, mesoderm and endoderm) [57]. These were shown to be effective in an in vivo mouse study, where human ESC-derived ECs were transplanted into mice and able to integrate into the host blood vessels and served as a vascular conduit that was functional for 150 days [58]. However, this has not yet been attempted in human studies. One of the main reasons is due to the risk of teratoma formation, which raises serious safety concerns [58,59]. Moreover, there is an ethical dilemma surrounding the use of human ESCs [60].
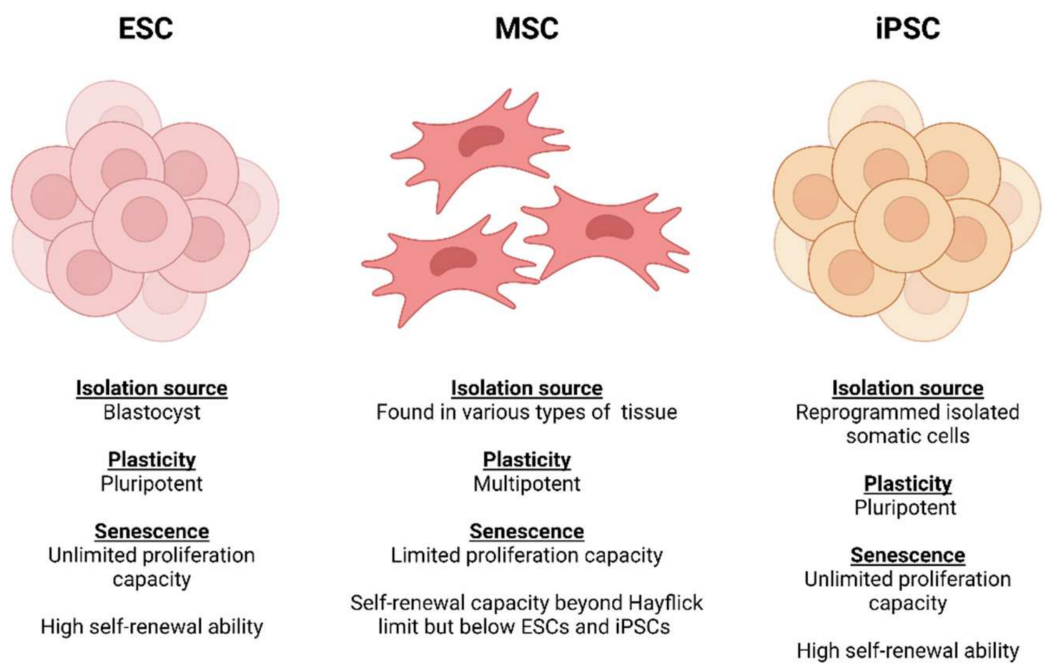

Figure 4. Comparisons of plasticity potential, source of extraction and senescence between stem cell sources (Created with Biorender.com, accessed on 8 January 2022).

\subsection{Mesenchymal Stem Cells}

Mesenchymal stem cells (MSCs) are cells with multipotent plasticity and self-renewal ability with mesodermal lineage differentiation potential [61]. The first successful isolation of MSCs was from mice bone marrow, reported by Friedenstein and colleagues in 1966. This was later achieved in humans by Haynesworth in $1992[62,63]$. Since then, MSCs have been discovered to reside in various types of adult and fetal tissues as well as being obtainable from multiple sources including dental pulp, tendon, muscle, umbilical cord, skin, liver, peripheral blood, hair follicle and adipose tissue. Due to their broad distribution and unique biological properties, MSCs have been extensively studied over last three decades for tissue engineering and regenerative medicine applications [64-66].

With the capability of differentiating into different lineages of mesodermal origin, MSCs have myogenic differentiation potential. Therefore, MSCs have been used to derive SMCs via the introduction of defined chemical factors and mechanotransduction signals. MSC derived VSMCs have been used in various blood vessel tissue engineering strategies to mimic the tunica media of the native vasculature [67-69]. Gong et al. [70] reported the first use of MSCs for engineering small-diameter blood vessel mimics. Using bone-marrow derived MSCs laden on tubular PGA mesh scaffolds and subsequent seeding of ECs to endothelialise the luminal surface, Gong et al. [70] fabricated a vessel mimic with MSC derived VSMCs that expressed SMC-specific markers and secreted native ECM proteins. The engineered vessels displayed a similar morphology to those of native vasculature [70]. More recently, Lacobazzi et al. [71] fabricated TEVGs by seeding the surface of a CorMatrix decellularised commercial cardiac patch with thymus derived MSCs. The TEVGs grafted 
on piglet left pulmonary artery models remained patent with no evidence of stenosis, rupture, thrombosis or tissue degradation three months post-engraftment. Furthermore, an organized VSMC population, an endothelialized luminal surface and a vascularised outer layer could be observed on the explanted TEVGs [71].

Compared to ESCs, MSCs have a more limited multipotent plasticity and rapidly lose their differentiation potency and telomerase activity during in vitro expansion due to senescence [72,73]. Furthermore, acquiring an acceptable quantity of MSCs from a single source has been identified as a major issue which hinders MSCs for clinical use and tissue engineering $[74,75]$. Despite these limitations, MSCs have been reported to hold remarkable genomic stability and tend to pose less significant ethical considerations compared to ESCs [61,76]. Also, MSCs have an advantage in terms of immunosuppressive characteristics. The expression of major histocompatibility complex (MHC) class I, Tolllike receptors (TLRs) and programmed death ligand 1 (PD-L1) proteins can protect MSCs from natural killer cells (NKs). Furthermore, MSCs have been shown to secrete antiinflammatory factors such as transforming growth factor $\beta$ (TGF- $\beta$ ) and hepatocyte growth factor (HGF) to inhibit the activation/functions of immune cells [77-79]. Due to these propitious characteristics, MSCs are believed to be capable of preventing immunogenic responses in the host tissue. The safety profile of MSCs has been well documented both in vitro and in vivo to support their safety for clinical uses. This has led to the registration of over 950 MSC-based clinical trials in the last 25 years, including approximately 70 registered cardiovascular injury repair therapies in the last decade. As a result, using MSCs to fabricate TEVGs for clinical applications continues to be extensively investigated and documented. Nevertheless, there is still no MSC-derived TEVG that has reached clinical application from trials $[66,74,80-82]$.

\subsection{Progenitor Cells}

Progenitor cells are another type of adult stem cell that specifically matures into its destined cell type. These progenitor cells can also be isolated from the bone marrow or blood, thus reducing the need for harvesting native vessels [83]. An ovine study showed that endothelial progenitor cell-based grafts provided effective patency, which was largely due to the production of nitrous oxide (NO) [84] that inhibits both platelet aggregation and VSMC proliferation and dilates blood vessels [85]. However, progenitor cells may be depleted in the elderly population, hence limiting their supply [86].

Adipose tissue also contains stem cells (ASCs), which can differentiate into both ECs and VSMCs $[87,88]$. The benefit of using ASCs is their wider availability and ease of harvest, even in the elderly population. Moreover, the number of ASCs seems unaffected by age, with evidence suggesting that their availability even increases with advanced age [89].

\subsection{Emergence of Induced Pluripotent Stem Cells (iPSCs)}

Despite the advances in employing ESCs and adult stem cells for vascular engineering, challenges including ethical issues, cell accessibility and heterogeneities remain which hinder the production of TEVGs. In 2006, there was a major breakthrough in stem cell biology - the emergence of induced pluripotent stem cells (iPSCs), which provides great potential to generate patient-specific cell types for vascular engineering [90-92]. Discovered by Dr Yamanaka and his team, iPSCs can be obtained via reprogramming adult somatic cells by inducing the four pluripotency factors: OCT-3/4, Sox2, Klf4 and c-Myc. The reprogrammed iPSCs possess the ability to differentiate into potentially any cell type of the three germ layers under defined conditions $[90,93]$.

There are numerous advantages associated with the use of iPSCs in vascular engineering. IPSCs provide a potentially unlimited cell source, since they could be derived from a number of easy-access tissues of the donor including the skin or peripheral blood, in addition to their excellent self-renewal capacity [94,95]. Using autologous cells that are derived from the same patient also addresses ethical dilemmas and reduces the risk of immunological reactions caused by the allogeneic cells [94]. Moreover, vascular abnor- 
malities caused by genetic mutations can be addressed by gene editing of the iPSCs from the patients to correct the DNA variants, which have potential therapeutic values [96,97]. A study by Luo et al. [98] demonstrated that human iPSC-derived TEVGs yielded impressive mechanical and contractile function, as well as excellent patency when implanted into a rat aortic model [98].

Although iPSCs provide a promising cell source for vascular tissue engineering, the technology also comes with a number of challenges. The most serious of these is the tumorigenesis risk associated with the pluripotent cells [99]. A study by Galat et al. [100] reported spontaneous transgene activation in iPSC vascular derivatives [100]. There were also reports that derivatives of iPSCs may not be immunologically inert due to the accumulation of mitochondrial DNA mutations. The reprogramming process can also lead to chromosomal rearrangement, thus increasing tumorigenic potential [100-102]. These issues present significant obstacles for the clinical use of iPSCs, as more stringent quality controls and screening measures are required, which inevitably increases the economic burden associated with iPSC therapies. Costs associated with preparing a biologically safe cell line can reach up to a million US dollars, which makes it less feasible to simply translate the technology to clinical practice [103]. Another issue is the time-consuming nature of the iPSC production, which needs to be optimised and standardised. Therefore, there is an urgent need to increase the safety, reduce the costs and improve the manufacturing processes associated with iPSCs before wider clinical applications are pursued. Table 2 highlights the advantages and disadvantages of the main cell types used in the production of TEVGs.

Table 2. Advantages and disadvantages of different cell types in vascular engineering.

\begin{tabular}{|c|c|c|c|c|}
\hline Cell Category & Cell Type & Advantages & Disadvantages & Reference \\
\hline $\begin{array}{l}\text { Autologous } \\
\text { somatic cells }\end{array}$ & $\begin{array}{c}\text { Vascular derived } \\
\text { ECs, SMCs and } \\
\text { fibroblasts, } \\
\text { Dermal fibroblasts }\end{array}$ & $\begin{array}{l}\text { Easy sourcing, } \\
\text { culture and } \\
\text { expansion. } \\
\text { Immune } \\
\text { compatibility. }\end{array}$ & $\begin{array}{l}\text { Invasive } \\
\text { harvesting risks } \\
\text { donor site } \\
\text { complications. } \\
\text { Limited } \\
\text { proliferative and } \\
\text { regenerative } \\
\text { capacities. }\end{array}$ & {$[16,51,104]$} \\
\hline Progenitor cells & $\begin{array}{c}\text { Vascular } \\
\text { endothelial } \\
\text { progenitor cells, } \\
\text { Bone } \\
\text { marrow-derived } \\
\text { SMC } \\
\text { progenitor cells }\end{array}$ & $\begin{array}{l}\text { Able to isolate } \\
\text { from bone marrow } \\
\text { and blood. } \\
\text { Greater replicative } \\
\text { and regenerative } \\
\text { potential. }\end{array}$ & $\begin{array}{l}\text { Availability may } \\
\text { be depleted in the } \\
\text { elderly population. }\end{array}$ & {$[80,83,106]$} \\
\hline $\begin{array}{l}\text { Mesenchymal } \\
\text { stem cells }\end{array}$ & $\begin{array}{c}\text { MSC } \\
\text { derived SMCs }\end{array}$ & $\begin{array}{l}\text { May be extracted } \\
\text { from multiple } \\
\text { sources. } \\
\text { Remarkable } \\
\text { genomic stability. }\end{array}$ & $\begin{array}{c}\text { Limited } \\
\text { differentiation into } \\
\text { ECs. } \\
\text { Rapidly lose their } \\
\text { differentiation } \\
\text { potency during } \\
\text { in vitro expansion. }\end{array}$ & {$[62,64,70,71,74-77]$} \\
\hline $\begin{array}{l}\text { Embryonic } \\
\text { stem cells }\end{array}$ & ESCs & $\begin{array}{c}\text { Ability of } \\
\text { self-renewal. } \\
\text { Can be } \\
\text { differentiated into } \\
\text { vascular ECs } \\
\text { and SMC. } \\
\text { Can be }\end{array}$ & $\begin{array}{l}\text { Safety concerns } \\
\text { (risk of teratoma } \\
\text { formation). } \\
\text { Ethical issues. }\end{array}$ & {$[57,58]$} \\
\hline $\begin{array}{l}\text { Human induced } \\
\text { pluripotent stem } \\
\text { cell (hiPSC) }\end{array}$ & $\begin{array}{l}\text { Wide range of } \\
\text { somatic cells }\end{array}$ & $\begin{array}{l}\text { differentiated into } \\
\text { any cell type. } \\
\text { Excellent } \\
\text { self-renewal } \\
\text { capacity. } \\
\text { Reduced risk of } \\
\text { immunogenicity. }\end{array}$ & $\begin{array}{c}\text { Risk of } \\
\text { tumorigenesis. } \\
\text { Expensive } \\
\text { process. Time } \\
\text { consuming } \\
\text { process. }\end{array}$ & {$[90,92,96,100]$} \\
\hline
\end{tabular}




\section{Cell-Seeding Techniques in Vascular Tissue Engineering}

SMCs and ECs are the two major cell types to be accommodated in vascular grafts. The vascular cells come from a variety of sources, as described below. Different techniques are also employed to assist with cell seeding and growth in the scaffolds.

\subsection{Passive Seeding}

The first reported TEVG fabrication by Weinberg and Bell in 1986 used a passive seeding method. Decades later, it remains the most common cell-seeding method used to fabricate TEVGs due to its low costs and ease of operation. Because of its simplicity, this approach is able to avoid cell damage from mechanical forces such as shear stress caused by the extensive manipulation of cells [107-109]. In fact, the most successful and longest ongoing TEVG clinical studies by Shin'oka and colleagues (NCT01034007 and NCT04467671) have used passive seeding to fabricate their vascular grafts [110-112]. This technique is performed via pipetting a cell suspension directly onto either the scaffold lumen or exterior followed by a short incubation to allow cell attachment (Figure 5) before the culture medium is added. The cell-laden scaffolds are then incubated for a period of time, and a tissue-like biological construct can be produced [109,113].

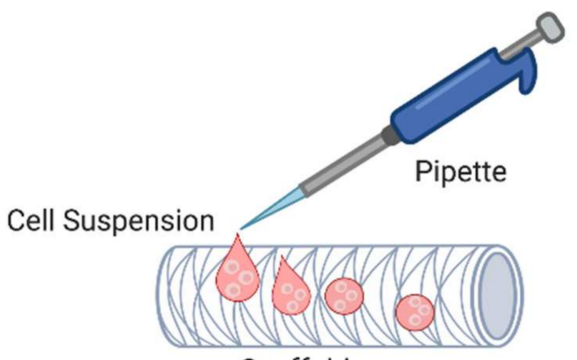

Scaffold

Figure 5. Passive seeding. Cell suspension is pipetted directly onto the lumen or exterior of the scaffold. (Created with BioRender.com, accessed on 8 January 2022).

The success of cell seeding is usually evaluated by the seeding efficiency which measures the percentage of total seeded cells attaching to the scaffolds over a short period of culture $(<24 \mathrm{~h})$ before cell doubling. Although it is the simplest and least expensive seeding technique, passive seeding has low cell-seeding efficiency [108,114,115]. Earlier efforts resulted in seeding efficiencies approximately $25 \%$ [116]. By including a degassing step to remove air pockets in the matrices prior to pipetting the cell suspension on to scaffolds, Vitacolonna et al. [117] demonstrated that the seeding efficiency could be improved to as high as $42 \%$ [117]. Nevertheless, despite this improvement, the efficiency of passive seeding remains significantly lower compared to other techniques like dynamic or electrostatic seeding (Table 3) $[114,116,118,119]$. Another drawback associated with the passive seeding technique is the suboptimal and heterogenous distribution of cells across the scaffold during seeding. This can lead to poor cell infiltration which inapt the recellularisation of scaffolds in the host and hinders ECs or mural cells from aligning similarly to the native vessels due to haphazard adhesion of the cells on the scaffold and the lack of physiological mechanotransduction cues during culture [120-122].

Table 3. Comparison of cell seeding efficiencies * between passive, dynamic (centrifugal, vacuum and perfusion) and electrostatic cell seeding methods.

\begin{tabular}{ccc}
\hline Cell Seeding Method & Seeding Efficiency & Reference \\
\hline Passive seeding & $10-42 \%$ & {$[110,116,117]$} \\
Centrifugal Seeding & $\sim 40-90 \%$ & {$[116,123-125]$} \\
Vacuum Seeding & $90 \% \geq$ & {$[109,126-128]$} \\
Perfusion Seeding & $50-90 \%$ & {$[129-132]$} \\
Electrostatic Seeding & $\sim 90 \%$ & {$[133-136]$} \\
\hline
\end{tabular}


To enhance the efficiency of the passive seeding, coating strategies have been used to overlay the surface of scaffolds with bioactive components. Biomaterials that are constituted of common ECM components found in the native vasculature such as fibronectin, fibrin as well as collagen or other natural sources like silk fibroin, have been used to coat the scaffold surfaces, and this has been shown to improve cell attachment and retention [137-140]. Nevertheless, despite these efforts, thrombogenicity remains prominent in TEVGs fabricated via passive seedling $[137,141]$. By conjugating coatings with anticoagulants or administering anticoagulant drug therapies, studies have attempted to reduce the rates of thrombosis. However, these alternatives give rise to other complications for patients requiring revascularisation surgery or other surgical procedures, as coagulation mechanisms are pivotal in wound healing, and therefore their inhibition increases the risk of haemorrhage $[110,142,143]$. These limitations have led to investigating alternative seeding techniques to improve seeding efficiency and the performance of TEVGs.

\subsection{Dynamic Seeding}

Dynamic seeding is a method that uses external forces during the seeding of cells onto a substrate of scaffold. This method has been shown to yield a more uniform or homogeneous distribution and penetration of adherent cells across seeded scaffolds compared to other methods $[127,130,144]$. Dynamic seeding can be applied via a wide range of techniques (Figure 6) using pressure, perfusion, stress, strain or centrifugal/centripetal force systems [145-148]. A common technique, vacuum seeding, essentially forces the cell suspension through the micropores of the engineered graft by utilising a pressure differential system [149]. Other typical techniques like perfusion or centrifugal systems use bioreactors to exert similar fluid dynamic forces as those observed in vivo or by driving cells onto a substrate via hydrostatic pressure from rotating inertial forces [111,130,150,151]. These methods present a rapid solution to achieving excellent seeding efficiencies of up to $\sim 90 \%[108,149]$. Furthermore, these systems are cheap and disposable and can be configured as an automated process to enhance reproducibility for clinical applications [152]. However, each technique has its own drawbacks. Reduced cell viability and changes in gene expression or cell morphology has been associated with centrifugal/vacuum methods. The complexity of the bioreactor systems and the long culture period are common disadvantages attributed to the perfusion techniques $[113,130,148]$. Complications such as failure, fatigue, and contamination are prominent risks with the prolonged culture of cells in bioreactors [108].

\subsection{Electrostatic Seeding}

The structure of the plasma membrane in mammalian cells is arranged in a phospholipid bilayer with negatively charged hydrophilic and non-polar hydrophobic regions $[153,154]$. Phosphates present in the hydrophilic heads of membranes provide the external surface with a negative charge. Electrostatic cell seeding techniques utilize the negatively charged characteristics of cell membranes by manipulating the electrostatic properties of the scaffold to promote cell attachment (Figure 7) [155-157]. This technique can yield seeding efficiencies as high as $\sim 90 \%$. Furthermore, electrostatic seeding has been shown to accelerate the maturation of cells via electrostatic phospholipid interactions and improve cell retention post-implantation, which decreases the risk of graft failure [104,134-136]. While this technique shows promise, it also has limitations. Via electrostatic forces, cells are driven to adhere to the surface of substrates; therefore, cells cannot be deeply embedded within scaffolds to generate tunica media-like structures. Additionally, high electrical conductivity in substrates may interfere with proper focal adhesion complex formation, which could reduce the proliferation potential of seeded cells [105]. Furthermore, there is a lack of studies regarding the long-term effects on cell viability and overall biological functions of TEVGs produced via electrostatic seeding methods. Hence, further research on its long-term outcomes in vivo is still required before translating this method to clinical use [105,108,149]. 
A.

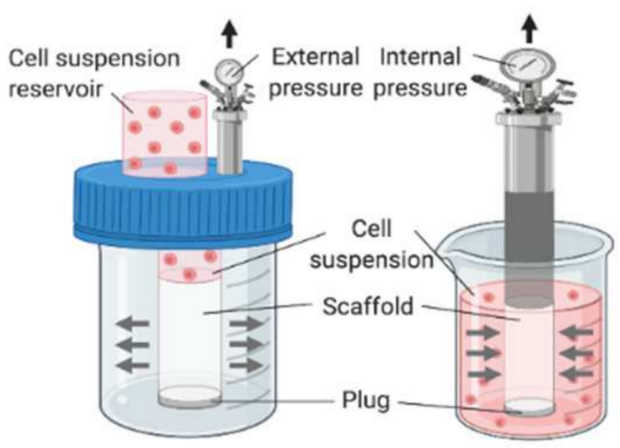

B.

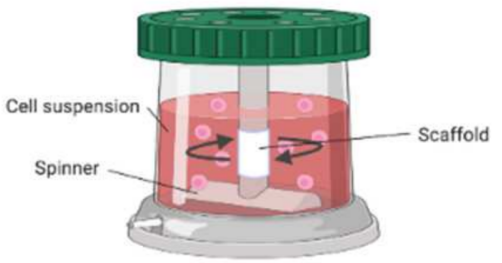

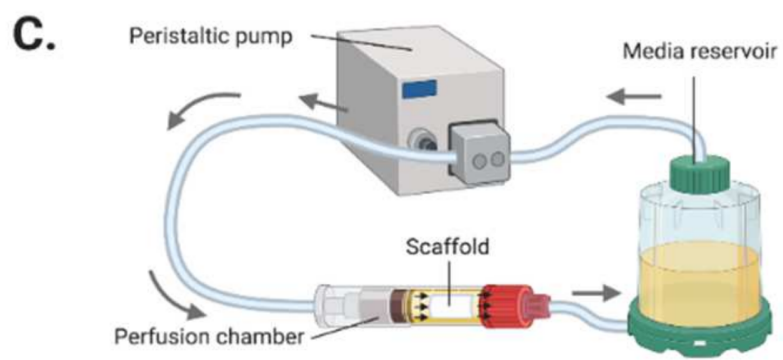

Figure 6. Dynamic seeding methods. (A) Vacuum seeding: using internal or external pressure forces to drive cells into scaffolds. (B) Centrifugal/rotational seeding: using rotational force to drives cells into the scaffold. (C) Perfusion seeding: mimicking the in vivo physiological conditions and biomechanical stress of blood vessels to aid cell attachment to the scaffold. (Created with BioRender.com, accessed on 8 January 2022).


Figure 7. Electrostatic seeding. Scaffolds are manipulated to become positively charged substrates to attract the negatively charged regions on cell membranes for increased retention and attachment of cells. Scaffolds can be chemically modified by either cross-linking polymers in pre-polymerised solutions during the fabrication process (1), or by covering scaffold surfaces with a thin conductive layer via atomic layer deposition post-fabrication (2). The negatively charged cells can then be seeded on to the positively charged scaffold (3). Negatively charged conductors can also be employed to repel cells to increase the efficiency of cell attachment on scaffolds. (Created with BioRender.com, accessed on 8 January 2022). 


\section{Maturation of TEVGs}

Once a TEVG has been loaded with cells, the next step is ensuring that it develops and matures into an effective graft for the implantation in vivo. As previously mentioned, there are mechanical requirements that need to be achieved to warrant the implantation of a TEVG. To ensure these criteria are met, the grafts need to go through a conditioning process for maturation and require proper testing prior to implantation [158]. This can be achieved through the introduction of pulsatile flow to remodel the vessel. Niklason et al. [159] proved that this process is necessary for VSMC migration throughout the scaffold [159]. Moreover, this mechanical stress leads to VSMC proliferation and differentiation, as well as ECM remodeling [98,159].

Following these findings, Niklason and colleagues pioneered the development of bioreactors as in vitro biomimetic flow systems [159]. By emulating the physiological conditions that blood vessels experience in vivo, other groups also demonstrated that the TEVGs matured to mimic the properties of native vessels through increased ECM formation, VSMC and EC differentiation, as well as migration [160,161]. Advancements in bioreactor technology have also minimised the risk of contamination through the automation of tissue culture, wireless data transfer and $\mathrm{pH}$ monitoring. However, the complexity of conditions required to produce grafts that fit these purposes remains a challenge $[160,162]$.

A major limitation of vascular conduits is the post implant stenosis secondary to excessive SMC proliferation, which is also known as intimal hyperplasia. This can lead to the loss of contractility of the vessel, which ultimately results in graft failure [163]. VSMCs express a spectrum of contractile and proliferative markers [164]. A high proliferative index is associated with a higher teratogenic potential, and vice versa. The characteristics of the contractile phenotype of VSMCs include the sensitivity to small molecular signalling (such as acetylcholine and noradrenaline), a high expression of contractile apparatus proteins, and a low proliferative index. On the other hand, the proliferative phenotype exhibits extensive ECM synthesis, low expression of contractile proteins, and a high proliferative index [163]. Studies have shown that it is possible to manipulate VSMCs to promote the expression of contractile marker genes to improve functioning. This can be achieved through signalling molecules such heparin and TGF- $\beta 1$, which inhibit proliferation and induce the expression of contractile proteins such as $\alpha$-SMA [165]. Additionally, studies have indicated that cyclic strain could increase the expression of the contractile genes as well as stimulate the production of ECM components which are necessary for cell survival [163]. Therefore, this provides further insight into the conditioning of seeded cells, which can aid the development of TEVGs.

\section{Clinical Applications}

Vascular tissue engineering has existed since the 1950s, but it was Weinberg and Bell who produced the first TEVG consisting of the main three layers (intima, media, adventitia) in 1986 [107]. Their approach used a combination of xenogeneic bovine vascular cells and collagen gels. Although this graft was weak (yielding a burst pressure of $10 \mathrm{mmHg}$ ), it gave vascular engineering a concept to build on and improve. Since then, several TEVGs have reached the clinical setting (Table 4).

Table 4. TEVGs that have reached clinical trials.

\begin{tabular}{|c|c|c|c|c|c|}
\hline Identifier & Application & Cell Type & Scaffold & Status & Reference \\
\hline NCT01034007 & Cavopulmonary shunt & Primary VSMCs & PGA & Completed & {$[106,166]$} \\
\hline NCT04467671 & Cavopulmonary shunt & Bone marrow mononuclear cells & PGA and PCLA & Recruiting & {$[82,167]$} \\
\hline NCT00850252 & AV shunt & Primary ECs and Fibroblasts & Scaffold-free & Completed & {$[39,168]$} \\
\hline NCT01744418 & AV shunt & Decellularised VSMCs & PGA & Active, not recruiting & {$[169,170]$} \\
\hline NCT01840956 & AV shunt & Decellularised VSMCs & PGA & Completed & {$[170,171]$} \\
\hline NCT03005418 & Vascular injury repair graft & Decellularised VSMCs & PGA & Recruiting & {$[172,173]$} \\
\hline
\end{tabular}


The first reported clinical application of a TEVG was performed by Shin'oka's group in 2001. This was a biodegradable pulmonary conduit composed of peripheral vein derived primary VSMCs from the same individual and PGA reinforced scaffold which was implanted in a child with congenital pulmonary atresia [174]. Results were positive, with patency being maintained for seven months post implantation. This study was then expanded to a further 23 paediatric patients with the same condition (NCT01034007) [166]. Follow-up at 5.8 years showed no graft-related mortality $[110,167]$. More recently, a secondgeneration TEVG derived from bone marrow mononuclear cells seeded on PGA and PCLA (Polycaprolactone-co-lactide) copolymer scaffolds by Shin'oka's group has been approved for a clinical trial in the safety phase (NCT04467671) This project has been active since July 2020 and is looking to improve on the outcomes of its predecessor [82,175].

L'Heureux subsequently developed the first sheet-based TEVG, the Lifeline graft. This approach utilises the induced production of ECM through culturing and maturation of autologous cells, rather than using an exogenous scaffold [38]. The graft was first tested in animal models, which confirmed that its mechanical stability was considerably higher than that of the human saphenous vein. Moreover, there was a good integration of the graft with the surrounding tissue, and no thrombus formation [52]. Following these promising results, the Lifeline graft was implanted into nine patients with end stage renal disease as part of a clinical trial (NCT00850252). Out of these, six patient had patent grafts at six months, whereas the other grafts failed from thrombosis or rejection [39]. Mechanical testing was undertaken before implantation, which confirmed that the average burst pressure was $3490 \mathrm{mmHg}$, matching the human internal mammary artery. However, the main drawback of the graft was the production time, which ranged from six to nine months, which is far too long and expensive for it to be introduced into routine clinical practice [52].

Since then, there has been a shift towards the use of decellularised scaffolds for engineered vessels - a key player being the Humacyte graft. Lawson et al. [170] used the grafts in clinical trials for end stage renal failure patients to provide AV shunt access for haemodialysis (NCT01744418 and NCT01840956) [169-171]. Results showed 63\% patency at six months, but only $18 \%$ at 18 months. These results still need to be improved in order to justify the high cost of the production. However, more recently, the Humacyte grafts have entered a new clinical trial (NCT03005418) to treat damaged vessels that require repair after vascular trauma, and they are currently recruiting for Phase 2 clinical trials [173]. Nonetheless, the results for their AV shunt application still need to be improved to justify the high cost of the production. Going forward, the focus needs to be on simplifying the design and manufacturing processes for TEVGs in order to produce off-the-shelf grafts for patients in urgent need of the product. Although Dahl et al. [176] laid the foundations for this concept, there is still a long way to go to validate a product for routine clinical practice.

\section{Conclusions and Future Perspectives}

The ultimate goal of vascular engineering is to produce clinically effective smalldiameter conduits that could integrate successfully in vivo to replace diseased vessels and meet the high demand for surgeries such as CABG [10]. The engineered vessel grafts need to resist thrombosis, maintain patency and withstand physiological stresses. Despite best efforts, the engineered vascular grafts still have not matched the performance of autologous vessels, therefore, there have not been commercially available small-diameter grafts [19]. More research needs to be undertaken to confirm the optimal cell types, scaffolding techniques and conditioning requirements to develop clinically appropriate TEVGs. Efforts should also be made to further our understanding of the in vivo integration and remodeling of small-diameter grafts to facilitate the innovation. Moreover, technologies for producing 'off-the-shelf' grafts which would ensure the availability of TEVGs in various clinical scenarios are waiting to be developed. It is likely that a combination of clinical outcomes and economic considerations will dictate the approaches and materials to be utilised for wider clinical applications. 


\begin{abstract}
Author Contributions: H.J. and T.W. conceptualized and designed the work. H.J. reviewed the literature and wrote the first version of the manuscript and prepared initial figures. L.L.M. made significant improvement to the draft and contributed in writing, referencing, reviewing and editing the manuscript and figures. T.W. made comments and revisions to the article. All authors have read and agreed to the published version of the manuscript.
\end{abstract}

Funding: This work is supported by a Ph.D. studentship (LL) from the Centre for Doctoral Training (CDT) in Regenerative Medicine programme funded by the Engineering and Physical Sciences Research Council (EPSRC) and Medical Research Council (MRC) (EP/L014904/1) on a project of vascular tissue engineering.

Data Availability Statement: Not applicable.

Acknowledgments: The authors would like to acknowledge Manchester Medical School for their Personal Excellence Programme (PEP) and the Centres for Doctoral Training (CDT) in Regenerative Medicine programme, which gave us an opportunity to write this manuscript.

Conflicts of Interest: The authors declare that they have no conflict of interest.

\title{
References
}

1. Jakobsson, L.; Kreuger, J.; Claesson-Welsh, L. Building Blood Vessels—Stem Cell Models in Vascular Biology. J. Cell Biol. 2007, 177, 751-755. [CrossRef] [PubMed]

2. Ramasamy, S.K. Structure and Functions of Blood Vessels and Vascular Niches in Bone. Stem Cells Int. 2017, 5046953. [CrossRef] [PubMed]

3. Hasan, A.; Paul, A.; Vrana, N.E.; Zhao, X.; Memic, A.; Hwang, S.; Dokmeci, M.R.; Khademhosseini, A. Microfluidic Techniques for Development of 3D Vascularized Tissue. Biomaterials 2014, 35, 7308-7325. [CrossRef]

4. Eble, J.; Niland, S. The Extracellular Matrix of Blood Vessels. Curr. Pharm. Des. 2009, 15, 1385-1400. [CrossRef]

5. $\quad$ Fruchart, J.C.; Nierman, M.C.; Stroes, E.S.G.; Kastelein, J.J.P.; Duriez, P. New Risk Factors for Atherosclerosis and Patient Risk Assessment. Circulation 2004, 109, 15-19. [CrossRef]

6. Criqui, M.H.; Aboyans, V. Epidemiology of Peripheral Artery Disease. Circ. Res. 2015, 116, 1509-1526. [CrossRef]

7. Alexander, J.; Smith, P. Coronary-Artery Bypass Grafting. N. Engl. J. Med. 2016, 374, 1954-1964. [CrossRef] [PubMed]

8. Berger, A.; MacCarthy, P.A.; Siebert, U.; Carlier, S.; Wijns, W.; Heyndrickx, G.; Bartunek, J.; Vanermen, H.; De Bruyne, B. Long-Term Patency of Internal Mammary Artery Bypass Grafts: Relationship with Preoperative Severity of the Native Coronary Artery Stenosis. Circulation 2004, 110, 36-40. [CrossRef] [PubMed]

9. Goldman, S.; Mcfalls, E.; Ward, H.B.; Kelly, R.F.; Tobler, G.H.; Harrison, L.; Wagner, T.H.; Wang, Y.; Planting, L.; Miller, M.; et al. Radial Artery Grafts vs Saphenous Vein Grafts in Coronary Artery Bypass Surgery. JAMA 2011, 305, 167-174. [CrossRef] [PubMed]

10. Carrabba, M.; Madeddu, P. Current Strategies for the Manufacture of Small Size Tissue Engineering Vascular Grafts. Front. Bioeng. Biotechnol. 2018, 6, 41. [CrossRef]

11. Pashneh-Tala, S.; MacNeil, S.; Claeyssens, F. The Tissue-Engineered Vascular Graft-Past, Present, and Future. Tissue Eng. Part B Rev. 2015, 22, 68-100. [CrossRef]

12. Peck, M.; Dusserre, N.; Mcallister, T.N.; Heureux, N.L. Tissue Engineering by Self-Assembly. Mater. Today 2011, 14, 218-224. [CrossRef]

13. Wystrychowski, W.; McAllister, T.N.; Zagalski, K.; Dusserre, N.; Cierpka, L.; L'Heureux, N. First Human Use of an Allogeneic Tissue-Engineered Vascular Graft for Hemodialysis Access. J. Vasc. Surg. 2014, 60, 1353-1357. [CrossRef]

14. Matsuzaki, Y.; John, K.; Shoji, T.; Shinoka, T. The Evolution of Tissue Engineered Vascular Graft Technologies: From Preclinical Trials to Advancing Patient Care. Appl. Sci. 2019, 9, 1274. [CrossRef]

15. Kim, T.H.; Yan, J.; Jang, J.Y.; Lee, G.; Lee, S.; Kim, B.S.; Chung, J.J.; Kim, S.H.; Jung, Y.; Yang, J. Tissue-Engineered Vascular Microphysiological Platform to Study Immune Modulation of Xenograft Rejection. Sci. Adv. 2021, 7, eabg2237. [CrossRef]

16. Zhang, W.J.; Liu, W.; Cui, L.; Cao, Y. Tissue Engineering of Blood Vessel. J. Cell. Mol. Med. 2007, 11, 945-957. [CrossRef] [PubMed]

17. Benrashid, E.; Mccoy, C.C.; Youngwirth, L.M.; Kim, J.; Manson, R.J.; Otto, J.C.; Lawson, J.H. Tissue Engineered Vascular Grafts: Origins, Development, and Current Strategies for Clinical Application. Methods 2016, 99, 13-19. [CrossRef]

18. Ben-shaul, S.; Landau, S.; Merdler, U.; Levenberg, S. Mature Vessel Networks in Engineered Tissue Promote Graft - Host Anastomosis and Prevent Graft Thrombosis. Proc. Natl. Acad. Sci. USA 2019, 116, 2955-2960. [CrossRef] [PubMed]

19. Neufurth, M.; Wang, X.; Tolba, E.; Dorweiler, B.; Schröder, H.; Link, T.; Diehl-Seifert, B.; Müller, W. Modular Small Diameter Vascular Grafts with Bioactive Functionalities. PLoS ONE 2015, 10, e0133632. [CrossRef]

20. Eltom, A.; Zhong, G.; Muhammad, A. Scaffold Techniques and Designs in Tissue Engineering Functions and Purposes: A Review. Adv. Mater. Sci. Eng. 2019, 3429527. [CrossRef]

21. Thottappillil, N.; Nair, P. Scaffolds in Vascular Regeneration: Current Status. Vasc. Health Risk Manag. 2015, 2015, 79-91.

22. O'Brien, F.J. Biomaterials \& Scaffolds for Tissue Engineering. Mater. Today 2011, 14, 88-95. 
23. Catto, V.; Farè, S.; Freddi, G.; Tanzi, M.C. Vascular Tissue Engineering: Recent Advances in Small Diameter Blood Vessel Regeneration. ISRN Vasc. Med. 2014, 923030. [CrossRef]

24. Dong, C.; Lv, Y. Application of Collagen Scaffold in Tissue Engineering: Recent Advances and New Perspectives. Polymers 2016, 8, 42. [CrossRef] [PubMed]

25. Meyer, M. Processing of Collagen Based Biomaterials and the Resulting Materials Properties. Biomed. Eng. Online 2019, 18, 24. [CrossRef] [PubMed]

26. Allen, A.; Priddy, L.; Li, M.T.; Guldberg, R. Functional Augmentation of Naturally-Derived Materials for Tissue Regeneration. Ann. Biomed. Eng. 2015, 43, 555-567. [CrossRef] [PubMed]

27. Guo, B.; Peter, X.M. Synthetic Biodegradable Functional Polymers for Tissue Engineering: A Brief Review. Sci. China Chem. 2014, 57, 490-500. [CrossRef]

28. Parisi, L.; Toffoli, A.; Ghiacci, G.; Macaluso, G.M. Tailoring the Interface of Biomaterials to Design Effective Scaffolds. J. Funct. Biomater. 2018, 9, 50. [CrossRef]

29. Niklason, L.E.; Langer, R.S. Advances in Tissue Engineering of Blood Vessels and Other Tissues. Transpl. Immunol. 1997, 5, 303-306. [CrossRef]

30. Gui, L.; Zhao, L.; Spencer, R.W.; Burghouwt, A.; Taylor, M.S.; Shalaby, S.W.; Niklason, L.E. Development of Novel Biodegradable Polymer Scaffolds for Vascular Tissue Engineering. Tissue Eng.-Part A 2011, 17, 1191-1200. [CrossRef]

31. Ul Ahad, I.; Bartnik, A.; Fiedorowicz, H.; Kostecki, J.; Korczyc, B.; Ciach, T.; Brabazon, D. Surface Modification of Polymers for Biocompatibility via Exposure to Extreme Ultraviolet Radiation. J. Biomed. Mater. Res.-Part A 2014, 102, 3298-3310. [CrossRef]

32. Ren, X.; Feng, Y.; Guo, J.; Wang, H.; Li, Q.; Yang, J.; Hao, X.; Lv, J.; Ma, N.; Li, W. Surface Modification and Endothelialization of Biomaterials as Potential Scaffolds for Vascular Tissue Engineering Applications. Chem. Soc. Rev. 2015, 44, 5680-5742. [CrossRef]

33. Tibbitt, M.W.; Anseth, K.S. Hydrogel as Extracellular Matrix Mimics for 3D Cell Culture. Biotechnol. Bioeng. 2009, 103, 655-663. [CrossRef] [PubMed]

34. Ravi, S.; Chaikof, E. Biomaterials for Vascular Tissue Engineering. Regen. Med. 2010, 5, 107-120. [CrossRef]

35. He, W.E.I.; Yong, T.; Teo, W.E.; Ma, Z. Fabrication and Endothelialization of Collagen-Blended Biodegradable Polymer Nanofibers: Potential Vascular Graft for Blood Vessel Tissue Engineering. Tissue Eng. 2005, 11, 1574-1588. [CrossRef]

36. Reid, J.A.; Callanan, A. Hybrid Cardiovascular Sourced Extracellular Matrix Scaffolds as Possible Platforms for Vascular Tissue Engineering. J. Biomed. Mater. Res.-Part B Appl. Biomater. 2020, 108, 910-924. [CrossRef] [PubMed]

37. Porzionato, A.; Stocco, E.; Barbon, S.; Grandi, F.; Macchi, V.; De Caro, R. Tissue-Engineered Grafts from Human Decellularized Extracellular Matrices: A Systematic Review and Future Perspectives. Int. J. Mol. Sci. 2018, 19, 4117. [CrossRef]

38. Heureux, N.L.; Dusserre, N.; Konig, G.; Victor, B.; Keire, P.; Wight, T.N.; Chronos, N.A.F.; Kyles, A.E.; Gregory, C.R.; Hoyt, G.; et al. Human Tissue-Engineered Blood Vessels for Adult Arterial Revascularization. Nat. Med. 2006, 12, 361-365. [CrossRef]

39. McAllister, T.N.; Maruszewski, M.; Garrido, S.A.; Wystrychowski, W.; Dusserre, N.; Marini, A.; Zagalski, K.; Fiorillo, A.; Avila, H.; Manglano, X.; et al. Effectiveness of Haemodialysis Access with an Autologous Tissue-Engineered Vascular Graft: A Multicentre Cohort Study. Lancet 2009, 373, 1440-1446. [CrossRef]

40. Liu, G.; He, Z.; Yang, D.; Han, X.; Guo, T.; Hao, C.; Hui, M.; Nie, C. Decellularized Aorta of Fetal Pigs as a Potential Scaffold for Small Diameter Tissue Engineered Vascular Graft. Chin. Med. J. 2008, 121, 1398-1406. [CrossRef]

41. Colunga, T.; Hayworth, M.; Kreß, S.; Reynolds, D.M.; Chen, L.; Nazor, K.L.; Baur, J.; Singh, A.M.; Loring, J.F.; Metzger, M.; et al. Human Pluripotent Stem Cell-Derived Multipotent Vascular Progenitors of the Mesothelium Lineage Have Utility in Tissue Engineering and Repair. Cell Rep. 2019, 26, 2566-2579.e10. [CrossRef] [PubMed]

42. Luo, J.; Shi, X.; Lin, Y.; Yuan, Y.; Kural, M.H.; Wang, J.; Ellis, M.W.; Anderson, C.W.; Zhang, S.M.; Riaz, M.; et al. Efficient Differentiation of Human Induced Pluripotent Stem Cells into Endothelial Cells under Xenogeneic-Free Conditions for Vascular Tissue Engineering. Acta Biomater. 2021, 119, 184-196. [CrossRef] [PubMed]

43. Lin, C.H.; Lu, J.H.; Hsia, K.; Lee, H.; Yao, C.L.; Ma, H. The Antithrombotic Function of Sphingosine-1-Phosphate on Human Adipose-Stem-Cell-Recellularized Tissue Engineered Vascular Graft in Vitro. Int. J. Mol. Sci. 2019, 20, 5218. [CrossRef] [PubMed]

44. Dukkipati, R.; Peck, M.; Dhamija, R.; Hentschel, D.M.; Reynolds, T.; Tammewar, G.; Mcallister, T. Biological Grafts for Hemodialysis Access: Historical Lessons, State-of-the-Art and Future Directions. Semin. Dial. 2013, 26, 233-239. [CrossRef]

45. Simionescu, A.; Schulte, J.B.; Fercana, G.; Simionescu, D.T. Inflammation in Cardiovascular Tissue Engineering: The Challenge to a Promise: A Minireview. Int. J. Inflam. 2011, 2011, 958247. [CrossRef]

46. Constable, M.; Burton, H.E.; Lawless, B.M.; Gramigna, V.; Buchan, K.G.; Espino, D.M. Effect of Glutaraldehyde Based CrossLinking on the Viscoelasticity of Mitral Valve Basal Chordae Tendineae. Biomed. Eng. Online 2018, 17, 93. [CrossRef]

47. Wang, X.; Ma, B.; Chang, J. Preparation of Decellularized Vascular Matrix by Co-Crosslinking of Procyanidins and Glutaraldehyde. Biomed. Mater. Eng. 2015, 26, 19-30. [CrossRef]

48. García Páez, J.M.; Jorge-Herrero, E.; Carrera, A.; Millán, I.; Rocha, A.; Calero, P.; Cordón, A.; Salvador, J.; Sainz, N.; Méndez, J.; et al. Chemical Treatment and Tissue Selection: Factors That Influence the Mechanical Behaviour of Porcine Pericardium. Biomaterials 2001, 22, 2759-2767. [CrossRef]

49. Shimizu, T.; Yamato, M.; Kikuchi, A.; Okano, T. Cell Sheet Engineering for Myocardial Tissue Reconstruction. Biomaterials 2003, 24, 2309-2316. [CrossRef]

50. Jung, Y.; Ji, H.; Chen, Z.; Fai Chan, H.; Atchison, L.; Klitzman, B.; Truskey, G.; Leong, K.W. Scaffold-Free, Human Mesenchymal Stem Cell-Based Tissue Engineered Blood Vessels. Sci. Rep. 2015, 5, 15116. [CrossRef] 
51. L'Heureux, N.; Pâquet, S.; Labbé, R.; Germain, L.; Auger, F.A. A Completely Biological Tissue-Engineered Human Blood Vessel. FASEB J. 1988, 12, 47-56.

52. Peck, M.; Gebhart, D.; Dusserre, N.; McAllister, T.N.; L'Heureux, N. The Evolution of Vascular Tissue Engineering and Current State of the Art. Cells Tissues Organs 2011, 195, 144-158. [CrossRef]

53. Saito, J.; Yokoyama, U.; Nakamura, T.; Kanaya, T.; Ueno, T.; Naito, Y.; Takayama, T.; Kaneko, M.; Miyagawa, S.; Sawa, Y.; et al. Scaffold-free Tissue-engineered Arterial Grafts Derived from Human Skeletal Myoblasts. Artif. Organs 2021, 1-14. [CrossRef] [PubMed]

54. Torensma, R. Blood Vessels Engineered from Human Cells. Lancet 2005, 366, 892; author reply 892-893. [CrossRef]

55. Song, H.H.G.; Rumma, R.T.; Ozaki, C.K.; Edelman, E.R.; Chen, C.S. Vascular Tissue Engineering: Progress, Challenges, and Clinical Promise. Cell Stem Cell 2018, 22, 340-354. [CrossRef]

56. Biehl, J.K.; Russell, B. Introduction to Stem Cell Therapy. J. Cardiovasc. Nurs. 2009, 24, 98-103. [CrossRef]

57. Wang, Y.; Yin, P.; Bian, G.-L.; Huang, H.-Y.; Shen, H.; Yang, J.-J.; Yang, Z.-Y.; Shen, Z.-Y. The Combination of Stem Cells and Tissue Engineering: An Advanced Strategy for Blood Vessels Regeneration and Vascular Disease Treatment. Stem Cell Res. Ther. 2017, 8, 194. [CrossRef]

58. Wang, Z.Z.; Au, P.; Chen, T.; Shao, Y.; Daheron, L.M.; Bai, H.; Arzigian, M.; Fukumura, D.; Jain, R.K.; Scadden, D.T. Endothelial Cells Derived from Human Embryonic Stem Cells Form Durable Blood Vessels in Vivo. Nat. Biotechnol. 2007, 25, 317-318. [CrossRef]

59. Hentze, H.; Soong, P.L.; Wang, S.T.; Phillips, B.W.; Putti, T.C.; Dunn, N.R. Teratoma Formation by Human Embryonic Stem Cells: Evaluation of Essential Parameters for Future Safety Studies. Stem Cell Res. 2009, 2, 198-210. [CrossRef]

60. Volarevic, V.; Markovic, B.S.; Gazdic, M.; Volarevic, A.; Jovicic, N.; Arsenijevic, N.; Armstrong, L.; Djonov, V.; Lako, M.; Stojkovic, M. Ethical and Safety Issues of Stem Cell-Based Therapy. Int. J. Med. Sci. 2018, 15, 36-45. [CrossRef]

61. Horwitz, E.M.; Le Blanc, K.; Dominici, M.; Mueller, I.; Slaper-Cortenbach, I.; Marini, F.C.; Deans, R.J.; Krause, D.S.; Keating, A. Clarification of the Nomenclature for MSC: The International Society for Cellular Therapy Position Statement. Cytotherapy 2005, 7, 393-395. [CrossRef] [PubMed]

62. Friedenstein, A.J.; Piatetzky-Shapiro, I.I.; Petrakova, K.V. Osteogenesis in Transplants of Bone Marrow Cells. J. Embryol. Exp. Morphol. 1966, 16, 381-390. [CrossRef] [PubMed]

63. Haynesworth, S.E.; Goshima, J.; Goldberg, V.M.; Caplan, A.I. Characterization of Cells with Osteogenic Potential from Human Marrow. Bone 1992, 13, 81-88. [CrossRef]

64. Hass, R.; Kasper, C.; Böhm, S.; Jacobs, R. Different Populations and Sources of Human Mesenchymal Stem Cells (MSC): A Comparison of Adult and Neonatal Tissue-Derived MSC. Cell Commun. Signal. 2011, 9, 12. [CrossRef]

65. Liu, J.Y.; Peng, H.F.; Gopinath, S.; Tian, J.; Andreadis, S.T. Derivation of Functional Smooth Muscle Cells from Multipotent Human Hair Follicle Mesenchymal Stem Cells. Tissue Eng.-Part A 2010, 16, 2553-2564. [CrossRef]

66. Pittenger, M.F.; Discher, D.E.; Péault, B.M.; Phinney, D.G.; Hare, J.M.; Caplan, A.I. Mesenchymal Stem Cell Perspective: Cell Biology to Clinical Progress. NPJ Regen. Med. 2019, 4, 22. [CrossRef] [PubMed]

67. Gong, Z.; Calkins, G.; Cheng, E.C.; Krause, D.N.L. Influence of Culture Medium on Smooth Muscle Cell. Tissue Eng. A 2009, 15, 319-330. [CrossRef]

68. Park, J.S.; Chu, J.S.; Tsou, A.D.; Diop, R.; Wang, A.; Li, S. The Effect of Matrix Stiffness on the Differentiation of Mesenchymal Stem Cells in Response to TGF- $\beta$. Biomaterials 2012, 32, 3921-3930. [CrossRef]

69. Wingate, K.; Bonani, W.; Tan, Y.; Bryant, S.; Tan, W. Compressive Elasticity of Three-Dimensional Nanofiber Matrix Directs Mesenchymal Stem Cell Differentiation to Vascular Cells with Endothelial or Smooth Muscle Cell Markers. Acta Biomater 2013, 8 , 1440-1449. [CrossRef]

70. Gong, Z.; Niklason, L.E. Small-Diameter Human Vessel Wall Engineered from Bone Marrow-Derived Mesenchymal Stem Cells (HMSCs). FASEB J. 2008, 22, 1365-1648. [CrossRef]

71. Iacobazzi, D.; Swim, M.M.; Albertario, A.; Caputo, M.; Ghorbel, M.T. Thymus-Derived Mesenchymal Stem Cells for Tissue Engineering Clinical-Grade Cardiovascular Grafts. Tissue Eng.-Part A 2018, 24, 794-808. [CrossRef]

72. Faiella, W.; Atoui, R. Therapeutic Use of Stem Cells for Cardiovascular Disease. Clin. Transl. Med. 2016, 5. [CrossRef] [PubMed]

73. Wang, Y.; Zhang, Z.; Chi, Y.; Zhang, Q.; Xu, F.; Yang, Z.; Meng, L.; Yang, S.; Yan, S.; Mao, A.; et al. Long-Term Cultured Mesenchymal Stem Cells Frequently Develop Genomic Mutations but Do Not Undergo Malignant Transformation. Cell Death Dis. 2013, 4, e950. [CrossRef] [PubMed]

74. Ullah, I.; Subbarao, R.B.; Rho, G.J. Human Mesenchymal Stem Cells - Current Trends and Future Prospective. Biosci. Rep. 2015, 35, e00191. [CrossRef] [PubMed]

75. Squillaro, T.; Peluso, G.; Galderisi, U. Clinical Trials with Mesenchymal Stem Cells: An Update. Cell Transplant. 2016, 25, 829-848. [CrossRef] [PubMed]

76. Chen, G.; Yue, A.; Ruan, Z.; Yin, Y.; Wang, R.; Ren, Y.; Zhu, L. Monitoring the Biology Stability of Human Umbilical Cord-Derived Mesenchymal Stem Cells during Long-Term Culture in Serum-Free Medium. Cell Tissue Bank. 2014, 15, 513-521. [CrossRef] [PubMed]

77. Giuliani, M.; Bennaceur-Griscelli, A.; Nanbaksh, A.; Oudrihiri, N.; Chouaib, S.; Durrbach, A.; Lataillade, J.-J. TLR Ligands Stimulation Protects MSC from NK Killing. Stem Cells 2014, 32, 290-300. [CrossRef] 
78. Reinders, M.E.J.; Hoogduijn, M.J. MSCs: Possible Implications for MSC Therapy in Renal Transplantation. J. Stem Cell Res. Ther. 2014, 4, 1000166. [CrossRef]

79. Hoogduijn, M.J. Are Mesenchymal Stromal Cells Immune Cells? Arthritis Res. Ther. 2015, 17, 88. [CrossRef]

80. Bandara, N.; Lim, S.; Chen, H.; Chen, S.; Wang, L.-X.; Strappe, P. The Proangiogenic Potential of Mesenchymal Stem Cells and Their Therapeutic Applications. In Mesenchymal Stem Cells: Isolation, Characterization and Applications; IntechOpen: London, UK, 2017.

81. Bajpai, V.K.; Andreadis, S.T. Stem Cell Sources for Vascular Tissue Engineering and Regeneration. Tissue Eng. Part B Rev. 2012, 18, 405-425. [CrossRef]

82. Galantowicz, M.; Breuer, C.; Shinoka, T. Two-Year Study of the Safety and Efficacy of the Second-Generation Tissue Engineered Vascular Grafts (TEVG-2). Available online: https: / / clinicaltrials.gov/ct2/show/NCT04467671 (accessed on 8 January 2022).

83. Asahara, T.; Murohara, T.; Sullivan, A.; Silver, M.; Van Der Zee, R.; Li, T.; Witzenbichler, B.; Schatteman, G.; Isner, J.M. Isolation of Putative Progenitor Endothelial Cells for Angiogenesis. Science 1997, 275, 964-967. [CrossRef]

84. Kaushal, S.; Amiel, G.E.; Guleserian, K.J.; Shapira, O.M.; Perry, T.; Sutherland, F.W.; Rabkin, E.; Moran, A.M.; Schoen, F.J.; Atala, A.; et al. Functional Small-Diameter Neovessels Created Using Endothelial Progenitor Cells Expanded Ex Vivo. Nat. Med. 2001, 7, 1035-1040. [CrossRef] [PubMed]

85. Tsihlis, N.D.; Oustwani, C.S.; Vavra, A.K.; Jiang, Q.; Keefer, L.K.; Kibbe, M.R. Nitric Oxide Inhibits Vascular Smooth Muscle Cell Proliferation and Neointimal Hyperplasia by Increasing the Ubiquitination and Degradation of UbcH10. Cell Biochem. Biophys. 2011, 60, 89-97. [CrossRef] [PubMed]

86. Gago, N.; Pérez-López, V.; Sanz-Jaka, J.P.; Cormenzana, P.; Eizaguirre, I.; Bernad, A.; Izeta, A. Age-Dependent Depletion of Human Skin-Derived Progenitor Cells. Stem Cells 2009, 27, 1164-1172. [CrossRef] [PubMed]

87. DiMuzio, P.; Tulenko, T. Tissue Engineering Applications to Vascular Bypass Graft Development: The Use of Adipose-Derived Stem Cells. J. Vasc. Surg. 2007, 45, A99-A103. [CrossRef]

88. Wang, C.; Yin, S.; Cen, L.; Liu, Q.; Liu, W.; Cao, Y.; Cui, L. Differentiation of Adipose-Derived Stem Cells into Contractile Smooth Muscle Cells Induced by Transforming Growth Factor-B1 and Bone Morphogenetic Protein-4. Tissue Eng.-Part A 2010, 16, 1201-1213. [CrossRef] [PubMed]

89. Zhang, P.; Moudgill, N.; Hager, E.; Tarola, N.; Dimatteo, C.; McIlhenny, S.; Tulenko, T.; Dimuzio, P.J. Endothelial Differentiation of Adipose-Derived Stem Cells from Elderly Patients with Cardiovascular Disease. Stem Cells Dev. 2011, 20, 977-988. [CrossRef]

90. Takahashi, K.; Yamanaka, S. Induction of Pluripotent Stem Cells from Mouse Embryonic and Adult Fibroblast Cultures by Defined Factors. Cell 2006, 126, 663-676. [CrossRef]

91. Lee, T.H.; Song, S.H.; Kim, K.L.; Yi, J.Y.; Shin, G.H.; Kim, J.Y.; Kim, J.; Han, Y.M.; Lee, S.H.; Lee, S.H.; et al. Functional Recapitulation of Smooth Muscle Cells via Induced Pluripotent Stem Cells from Human Aortic Smooth Muscle Cells. Circ. Res. 2010, 106, 120-128. [CrossRef]

92. Choi, K.; Yu, J.; Smuga-otto, K.; Salvagiotto, G.; Rehrauer, W.; Vodyanik, M.; Thomson, J.; Slukvin, I. Hematopoietic and Endothelial Differentiation of Human Induced Pluripotent Stem Cells. Stem Cells 2009, 27, 559-567. [CrossRef]

93. Takahashi, K.; Tanabe, K.; Ohnuki, M.; Narita, M.; Ichisaka, T.; Tomoda, K.; Yamanaka, S. Induction of Pluripotent Stem Cells from Adult Human Fibroblasts by Defined Factors. Cell 2007, 131, 861-872. [CrossRef]

94. Pereira, I.M.; Marote, A.; Salgado, A.J.; Silva, N.A. Filling the Gap: Neural Stem Cells as a Promising Therapy for Spinal Cord Injury. Pharmaceuticals 2019, 12, 65. [CrossRef]

95. Nakayama, K.H.; Joshi, P.A.; Lai, E.S.; Gujar, P.; Joubert, L.M.; Chen, B.; Huang, N.F. Bilayered Vascular Graft Derived from Human Induced Pluripotent Stem Cells with Biomimetic Structure and Function. Regen. Med. 2015, 10, 745-755. [CrossRef] [PubMed]

96. Sanjurjo-Soriano, C.; Erkilic, N.; Baux, D.; Mamaeva, D.; Hamel, C.P.; Meunier, I.; Roux, A.F.; Kalatzis, V. Genome Editing in Patient IPSCs Corrects the Most Prevalent USH2A Mutations and Reveals Intriguing Mutant MRNA Expression Profiles. Mol. Ther.-Methods Clin. Dev. 2020, 17, 156-173. [CrossRef]

97. Eoh, J.H.; Shen, N.; Burke, J.A.; Hinderer, S.; Xia, Z.; Schenke-Layland, K.; Gerecht, S. Enhanced Elastin Synthesis and Maturation in Human Vascular Smooth Muscle Tissue Derived from Induced-Pluripotent Stem Cells. Acta Biomater. 2017, 52, 49-59. [CrossRef]

98. Luo, J.; Qin, L.; Zhao, L.; Gui, L.; Ellis, M.W.; Huang, Y.; Kural, M.H.; Clark, J.A.; Ono, S.; Wang, J.; et al. Tissue-Engineered Vascular Grafts with Advanced Mechanical Strength from Human IPSCs. Cell Stem Cell 2020, 26, 251-261.e8. [CrossRef]

99. Lee, A.S.; Tang, C.; Rao, M.S.; Weissman, I.L.; Wu, J.C. Tumorigenicity as a Clinical Hurdle for Pluripotent Stem Cell Therapies. Nat. Med. 2013, 19, 998-1004. [CrossRef] [PubMed]

100. Galat, V.; Galat, Y.; Perepitchka, M.; Jennings, L.J.; Iannaccone, P.M.; Hendrix, M.J.C. Transgene Reactivation in Induced Pluripotent Stem Cell Derivatives and Reversion to Pluripotency of Induced Pluripotent Stem Cell-Derived Mesenchymal Stem Cells. Stem Cells Dev. 2016, 25, 1060-1072. [CrossRef]

101. Deuse, T.; Hu, X.; Agbor-Enoh, S.; Koch, M.; Spitzer, M.H.; Gravina, A.; Alawi, M.; Marishta, A.; Peters, B.; Kosaloglu-Yalcin, Z.; et al. De Novo Mutations in Mitochondrial DNA of IPSCs Produce Immunogenic Neoepitopes in Mice and Humans. Nat. Biotechnol. 2019, 37, 1137-1144. [CrossRef] [PubMed]

102. Turinetto, V.; Orlando, L.; Giachino, C. Induced Pluripotent Stem Cells: Advances in the Quest for Genetic Stability during Reprogramming Process. Int. J. Mol. Sci. 2017, 18, 1952. [CrossRef] [PubMed] 
103. Ortuño-Costela, M.D.C.; Cerrada, V.; García-López, M.; Gallardo, M.E. The Challenge of Bringing IPSCs to the Patient. Int. J. Mol. Sci. 2019, 20, 6305. [CrossRef] [PubMed]

104. Shayan, M.; Chen, Y.; Shridhar, P.; Kealey, C.; Chun, Y. In Vitro Study of a Superhydrophilic Thin Film Nitinol Endograft That Is Electrostatically Endothelialized in the Catheter Prior to the Endovascular Procedure. J. Funct. Biomater. 2016, 7, 31. [CrossRef] [PubMed]

105. Choi, W.J.; Jung, J.; Lee, S.; Chung, Y.J.; Yang, C.S.; Lee, Y.K.; Lee, Y.S.; Park, J.K.; Ko, H.W.; Lee, J.O. Effects of Substrate Conductivity on Cell Morphogenesis and Proliferation Using Tailored, Atomic Layer Deposition-Grown ZnO Thin Films. Sci. Rep. 2015, 5, 9974. [CrossRef] [PubMed]

106. Shinoka, T.; Breuer, C. Tissue-Engineered Blood Vessels in Pediatric Cardiac Surgery. Yale J. Biol. Med. 2008, 81, 161-166.

107. Weinberg, C.B.; Bell, E. A Blood Vessel Model Constructed from Collagen and Cultured Vascular Cells. Science 1986, 231, 397-400. [CrossRef] [PubMed]

108. Weinbaum, J.S.; Haskett, D.G.; Mandelkern, T.F.; Vorp, D.A. Advances in Cell Seeding of Tissue Engineered Vascular Grafts. In Tissue-Engineered Vascular Grafts; Springer: Berlin, Germany, 2020; pp. 295-319.

109. Solchaga, L.A.; Tognana, E.; Penick, K.; Baskaran, H.; Goldberg, V.M.; Caplan, A.I.; Welter, J.F. A Rapid Seeding Technique for the Assembly of Large Cell/Scaffold Composite Constructs. Tissue Eng. 2006, 12, 1851-1863. [CrossRef]

110. Hibino, N.; McGillicuddy, E.; Matsumura, G.; Ichihara, Y.; Naito, Y.; Breuer, C.; Shinoka, T. Late-Term Results of Tissue-Engineered Vascular Grafts in Humans. J. Thorac. Cardiovasc. Surg. 2010, 139, 431-436.e2. [CrossRef]

111. Lee, Y.U.; Mahler, N.; Best, C.A.; Tara, S.; Sugiura, T.; Lee, A.Y.; Yi, T.; Hibino, N.; Shinoka, T.; Breuer, C. Rational Design of an Improved Tissue-Engineered Vascular Graft: Determining the Optimal Cell Dose and Incubation Time. Regen. Med. 2016, 11, 159-167. [CrossRef]

112. Shinoka, T. What Is the Best Material for Extracardiac Fontan Operation? J. Thorac. Cardiovasc. Surg. 2017, 153, 1551-1552. [CrossRef]

113. Udelsman, B.; Hibino, N.; Villalona, G.A.; McGillicuddy, E.; Nieponice, A.; Sakamoto, Y.; Matsuda, S.; Vorp, D.A.; Shinoka, T.; Breuer, C.K. Development of an Operator-Independent Method for Seeding Tissue-Engineered Vascular Grafts. Tissue Eng.-Part C Methods 2011, 17, 731-736. [CrossRef]

114. Popov, G.I.; Kryukov, A.E.; Popryadukhin, P.V.; Naschekina, Y.A.; Ivankova, E.M.; Vavilov, V.N.; Yudin, V.E.; Smirnova, N.V. Optimal Methods of Cell Seeding and Cultivation on a Poly(L-Lactide) Biodegradable Scaffold. Cell Tissue Biol. 2018, 12, 359-366. [CrossRef]

115. Liu, Z.; Tamaddon, M.; Gu, Y.; Yu, J.; Xu, N.; Gang, F. Cell Seeding Process Experiment and Simulation on Three-Dimensional Polyhedron and Cross-Link Design Scaffolds. Front. Bioeng. Biotechnol. 2020, 8, 104. [CrossRef]

116. Roh, J.D.; Nelson, G.N.; Udelsman, B.V.; Brennan, M.P.; Lockhart, B.; Fong, P.M.; Lopez-Soler, R.I.; Saltzman, W.M.; Breuer, C.K. Centrifugal Seeding Increases Seeding Efficiency and Cellular Distribution of Bone Marrow Stromal Cells in Porous Biodegradable Scaffolds. Tissue Eng. 2007, 13, 2743-2749. [CrossRef] [PubMed]

117. Vitacolonna, M.; Belharazem, D.; Hohenberger, P.; Roessner, E.D. Effect of Static Seeding Methods on the Distribution of Fibroblasts within Human Acellular Dermis. Biomed. Eng. Online 2013, 12, 55. [CrossRef] [PubMed]

118. Hofmann, S.; Hagenmüller, H.; Koch, A.M.; Müller, R.; Vunjak-Novakovic, G.; Kaplan, D.L.; Merkle, H.P.; Meinel, L. Control of in Vitro Tissue-Engineered Bone-like Structures Using Human Mesenchymal Stem Cells and Porous Silk Scaffolds. Biomaterials 2007, 28, 1152-1162. [CrossRef] [PubMed]

119. Shimizu, K.; Ito, A.; Arinobe, M.; Murase, Y.; Iwata, Y.; Narita, Y.; Kagami, H.; Ueda, M.; Honda, H. Effective Cell-Seeding Technique Using Magnetite Nanoparticles and Magnetic Force onto Decellularized Blood Vessels for Vascular Tissue Engineering J. Biosci. Bioeng. 2007, 103, 472-478. [CrossRef] [PubMed]

120. Thevenot, P.; Nair, A.; Dey, J.; Yang, J.; Tang, L. Method to Analyze Three-Dimensional Cell Distribution and Infiltration in Degradable Scaffolds. Tissue Eng.-Part C Methods 2008, 14, 319-331. [CrossRef]

121. Jeong, G.S.; Oh, J.; Kim, S.B.; Dokmeci, M.R.; Bae, H.; Lee, S.H.; Khademhosseini, A. Siphon-Driven Microfluidic Passive Pump with a Yarn Flow Resistance Controller. Lab Chip 2014, 14, 4213-4219. [CrossRef]

122. van Dijk, C.G.M.; Brandt, M.M.; Poulis, N.; Anten, J.; van der Moolen, M.; Kramer, L.; Homburg, E.F.G.A.; Louzao-Martinez L.; Pei, J.; Krebber, M.M.; et al. A New Microfluidic Model That Allows Monitoring of Complex Vascular Structures and Cell Interactions in a 3D Biological Matrix. Lab Chip 2020, 20, 1827-1844. [CrossRef]

123. Zhang, Z.Z.; Jiang, D.; Wang, S.J.; Qi, Y.S.; Zhang, J.Y.; Yu, J.K. Potential of Centrifugal Seeding Method in Improving Cells Distribution and Proliferation on Demineralized Cancellous Bone Scaffolds for Tissue-Engineered Meniscus. ACS Appl. Mater. Interfaces 2015, 7, 15294-15302. [CrossRef]

124. Vitacolonna, M.; Belharazem, D.; Hohenberger, P.; Roessner, E.D. Effect of Dynamic Seeding Methods on the Distribution of Fibroblasts within Human Acellular Dermis. Cell Tissue Bank. 2015, 16, 605-614. [CrossRef]

125. Thönnes, S.; Shelton, P.; Bracey, D.N.; Van Dyke, M.; Whitlock, P.; Smith, T.L.; Moghaddam, A.; Tuohy, C. Success and Efficiency of Cell Seeding in Avian Tendon Xenografts-A Promising Alternative for Tendon and Ligament Reconstruction. J. Orthop. 2020, 18, 155-161. [CrossRef]

126. van Wachem, P.B.; Stronck, J.W.S.; Koers-Zuideveld, R.; Dijk, F.; Wildevuur, C.R.H. Vacuum Cell Seeding: A New Method for the Fast Application of an Evenly Distributed Cell Layer on Porous Vascular Grafts. Biomaterials 1990, 11, 602-606. [CrossRef] 
127. Buizer, A.T.; Veldhuizen, A.G.; Bulstra, S.K.; Kuijer, R. Static versus Vacuum Cell Seeding on High and Low Porosity Ceramic Scaffolds. J. Biomater. Appl. 2014, 29, 3-13. [CrossRef] [PubMed]

128. Haskett, D.G.; Saleh, K.S.; Lorentz, K.L.; Josowitz, A.D.; Luketich, S.K.; Weinbaum, J.S.; Kokai, L.E.; D'Amore, A.; Marra, K.G.; Rubin, J.P.; et al. An Exploratory Study on the Preparation and Evaluation of a "Same-Day" Adipose Stem Cell-Based Tissue-Engineered Vascular Graft. J. Thorac. Cardiovasc. Surg. 2018, 156, 1814-1822.e3. [CrossRef]

129. Wendt, D.; Marsano, A.; Jakob, M.; Heberer, M.; Martin, I. Oscillating Perfusion of Cell Suspensions through Three-Dimensional Scaffolds Enhances Cell Seeding Efficiency and Uniformity. Biotechnol. Bioeng. 2003, 84, 205-214. [CrossRef] [PubMed]

130. Zhao, F.; Ma, T. Perfusion Bioreactor System for Human Mesenchymal Stem Cell Tissue Engineering: Dynamic Cell Seeding and Construct Development. Biotechnol. Bioeng. 2005, 91, 482-493. [CrossRef]

131. Koch, M.A.; Vrij, E.J.; Engel, E.; Planell, J.A.; Lacroix, D. Perfusion Cell Seeding on Large Porous PLA/Calcium Phosphate Composite Scaffolds in a Perfusion Bioreactor System under Varying Perfusion Parameters. J. Biomed. Mater. Res.-Part A 2010, 95, 1011-1018. [CrossRef] [PubMed]

132. Maidhof, R.; Marsano, A.; Lee, E.J.; Vunjak-Novakovic, G. Perfusion Seeding of Channeled Elastomeric Scaffolds with Myocytes and Endothelial Cells for Cardiac Tissue Engineering. Biotechnol. Prog. 2010, 26, 565-572. [CrossRef] [PubMed]

133. Bowlin, G.L.; Rittgers, S.E.; Milsted, A.; Schmidt, S.P. In Vitro Evaluation of Electrostatic Endothelial Cell Transplantation onto 4 Mm Interior Diameter Expanded Polytetrafluroethylene Grafts. J. Vasc. Surg. 1998, 27, 504-511. [CrossRef]

134. Bowlin, G.L.; Meyer, A.; Fields, C.; Cassano, A.; Makhoul, R.G.; Allen, C.; Rittgers, S.E. The Persistence of Electrostatically Seeded Endothelial Cells Lining a Small Diameter Expanded Polytetrafluoroethylene Vascular Graft. J. Biomater. Appl. 2001, 16, 157-173. [CrossRef]

135. Fields, C.; Cassano, A.; Makhoul, R.G.; Allen, C.; Sims, R.; Bulgrin, J.; Meyer, A.; Bowlin, G.L.; Rittgers, S.E. Evaluation of Electrostatically Endothelial Cell Seeded Expanded Polytetrafluoroethylene Grafts in a Canine Femoral Artery Model. J. Biomater. Appl. 2002, 17, 135-152. [CrossRef]

136. Grinstein, S. Imaging Signal Transduction during Phagocytosis: Phospholipids, Surface Charge, and Electrostatic Interactions. Am. J. Physiol.-Cell Physiol. 2010, 299, 876-881. [CrossRef] [PubMed]

137. Ramalanjaona, G.; Kempczinski, R.F.; Rosenman, J.E.; Charles Douville, E.; Silberstein, E.B. The Effect of Fibronectin Coating on Endothelial Cell Ldnetics in Polytetrafluoroethylene Grafts. J. Vasc. Surg. 1986, 3, 264-272. [CrossRef]

138. Pankajakshan, D.; Philipose, L.P.; Palakkal, M.; Krishnan, K.; Krishnan, L.K. Development of a Fibrin Composite-Coated Poly( $\varepsilon-$ Caprolactone) Scaffold for Potential Vascular Tissue Engineering Applications. J. Biomed. Mater. Res.-Part B Appl. Biomater. 2008, 87, 570-579. [CrossRef] [PubMed]

139. Khan, M.; Yang, J.; Shi, C.; Lv, J.; Feng, Y.; Zhang, W. Surface Tailoring for Selective Endothelialization and Platelet Inhibition via a Combination of SI-ATRP and Click Chemistry Using Cys-Ala-Gly-Peptide. Acta Biomater. 2015, 20, 69-81. [CrossRef]

140. Zamani, M.; Khafaji, M.; Naji, M.; Vossoughi, M.; Alemzadeh, I.; Haghighipour, N. A Biomimetic Heparinized Composite Silk-Based Vascular Scaffold with Sustained Antithrombogenicity. Sci. Rep. 2017, 7, 4455.

141. Charbonier, F.W.; Zamani, M.; Huang, N.F. Endothelial Cell Mechanotransduction in the Dynamic Vascular Environment. Adv. Biosyst. 2019, 3, 1800252. [CrossRef] [PubMed]

142. Bruinsma, B.G.; Kim, Y.; Berendsen, T.A.; Ozer, S.; Yarmush, M.L.; Uygun, B.E. Layer-by-Layer Heparinization of Decellularized Liver Matrices to Reduce Thrombogenicity of Recellularized Liver Grafts. J. Clin. Transl. Res. 2015, 2015, 48-56.

143. Shoeb, M.; Fang, M.C. Assessing Bleeding Risk in Patients Taking Anticoagulants. J. Thromb. Thrombolysis 2013, 35, 312-319. [CrossRef] [PubMed]

144. Vunjak-Novakovic, G.; Obradovic, B.; Martin, I.; Bursac, P.M.; Langer, R.; Freed, L.E. Dynamic Cell Seeding of Polymer Scaffolds for Cartilage Tissue Engineering. Biotechnol. Prog. 1998, 14, 193-202. [CrossRef] [PubMed]

145. Torigoe, I.; Sotome, S.; Tsuchiya, A.; Yoshii, T.; Takahashi, M.; Kawabata, S.; Shinomiya, K. Novel Cell Seeding System into a Porous Scaffold Using a Modified Low-Pressure Method to Enhance Cell Seeding Efficiency and Bone Formation. Cell Transplant. 2007, 16, 729-739. [CrossRef] [PubMed]

146. Schmid, J.; Schwarz, S.; Meier-Staude, R.; Sudhop, S.; Clausen-Schaumann, H.; Schieker, M.; Huber, R. A Perfusion Bioreactor System for Cell Seeding and Oxygen-Controlled Cultivation of Three-Dimensional Cell Cultures. Tissue Eng.-Part C Methods 2018, 24, 585-595. [CrossRef] [PubMed]

147. Stekelenburg, M.; Rutten, M.C.M.; Snoeckx, L.H.E.H.; Baaijens, F.P.T. Dynamic Straining Combined with Fibrin Gel Cell Seeding Improves Strength of Tissue-Engineered Small-Diameter Vascular Grafts. Tissue Eng.-Part A 2009, 15, 1081-1089. [CrossRef]

148. Godbey, W.T.; Stacey Hindy, B.S.; Sherman, M.E.; Atala, A. A Novel Use of Centrifugal Force for Cell Seeding into Porous Scaffolds. Biomaterials 2004, 25, 2799-2805. [CrossRef] [PubMed]

149. Villalona, G.A.; Udelsman, B.; Duncan, D.R.; McGillicuddy, E.; Sawh-Martinez, R.F.; Hibino, N.; Painter, C.; Mirensky, T.; Erickson, B.; Shinoka, T.; et al. Cell-Seeding Techniques in Vascular Tissue Engineering. Tissue Eng. Part B Rev. 2010, 16, 341-350. [CrossRef] [PubMed]

150. Reynolds, P.M.; Rasmussen, C.H.; Hansson, M.; Dufva, M.; Riehle, M.O.; Gadegaard, N. Controlling Fluid Flow to Improve Cell Seeding Uniformity. PLoS ONE 2018, 13, e0207211. [CrossRef] [PubMed]

151. Detzel, C.J.; Van Wie, B.J. Use of a Centrifugal Bioreactor for Cartilaginous Tissue Formation from Isolated Chondrocytes. Biotechnol. Prog. 2011, 27, 451-459. [CrossRef] 
152. Hsu, S.H.; Tsai, I.J.; Lin, D.J.; Chen, D.C. The Effect of Dynamic Culture Conditions on Endothelial Cell Seeding and Retention on Small Diameter Polyurethane Vascular Grafts. Med. Eng. Phys. 2005, 27, 267-272. [CrossRef]

153. Westheimer, F.H. Why Nature Chose Phosphates. Science 1987, 235, 1173-1178. [CrossRef]

154. Zhang, S. Lipid-like Self-Assembling Peptides. Acc. Chem. Res. 2012, 45, 2142-2150. [CrossRef]

155. van Wachem, P.B.; Hogt, A.H.; Beugeling, T.; Feijen, J.; Bantjes, A.; Detmers, J.P.; van Aken, W.G. Adhesion of Cultured Human Endothelial Cells onto Methacrylate Polymers with Varying Surface Wettability and Charge. Biomaterials 1987, 8, 323-328. [CrossRef]

156. Hasturk, O.; Sahoo, J.K.; Kaplan, D.L. Synthesis and Characterization of Silk Ionomers for Layer-by-Layer Electrostatic Deposition on Individual Mammalian Cells. Biomacromolecules 2020, 21, 2829-2843. [CrossRef]

157. Santa-Maria, A.R.; Walter, F.R.; Valkai, S.; Brás, A.R.; Mészáros, M.; Kincses, A.; Klepe, A.; Gaspar, D.; Castanho, M.A.R.B.; Zimányi, L.; et al. Lidocaine Turns the Surface Charge of Biological Membranes More Positive and Changes the Permeability of Blood-Brain Barrier Culture Models. Biochim. Biophys. Acta-Biomembr. 2019, 1861, 1579-1591. [CrossRef]

158. Gui, L.; Dash, B.C.; Luo, J.; Qin, L.; Zhao, L.; Hashimoto, T.; Wu, H.; Dardik, A.; Tellides, G. Implantable Tissue-Engineered Blood Vessels from Human Induced Pluripotent Stem Cells. Biomaterials. 2016, 102, 120-129. [CrossRef]

159. Niklason, L.E.; Gao, J.; Abbott, W.M.; Hirschi, K.K.; Houser, S.; Marini, R.; Langer, R. Functional Arteries Grown in Vitro. Science 1999, 284, 489-493. [CrossRef] [PubMed]

160. Maschhoff, P.; Heene, S.; Lavrentieva, A.; Hentrop, T.; Leibold, C.; Wahalla, M.N.; Stanislawski, N.; Blume, H.; Scheper, T.; Blume, C. An Intelligent Bioreactor System for the Cultivation of a Bioartificial Vascular Graft. Eng. Life Sci. 2017, 17, 567-578. [CrossRef] [PubMed]

161. Thomas, L.V.; Nair, P.D. The Effect of Pulsatile Loading and Scaffold Structure for the Generation of a Medial Equivalent Tissue Engineered Vascular Graft. Biores. Open Access 2013, 2, 227-239. [CrossRef] [PubMed]

162. Song, L.; Zhou, Q.; Duan, P.; Guo, P.; Li, D.; Xu, Y.; Li, S.; Luo, F.; Zhang, Z. Successful Development of Small Diameter Tissue-Engineering Vascular Vessels by Our Novel Integrally Designed Pulsatile Perfusion-Based Bioreactor. PLoS ONE 2012, 7, e42569. [CrossRef]

163. Beamish, J.A.; He, P.; Kottke-Marchant, K.; Marchant, R.E. Molecular Regulation of Contractile Smooth Muscle Cell Phenotype: Implications for Vascular Tissue Engineering. Tissue Eng. Part B Rev. 2010, 16, 467-491. [CrossRef]

164. Owens, G.K.; Kumar, M.S.; Wamhoff, B.R. Molecular Regulation of Vascular Smooth Muscle Cell Differentiation in Development and Disease. Physiol. Rev. 2004, 84, 767-801. [CrossRef] [PubMed]

165. Hayashi, K.; Shibata, K.; Morita, T.; Iwasaki, K.; Watanabe, M.; Sobue, K. Insulin Receptor Substrate-1/SHP-2 Interaction, a Phenotype-Dependent Switching Machinery of Insulin-like Growth Factor-I Signaling in Vascular Smooth Muscle Cells. J. Biol. Chem. 2004, 279, 40807-40818. [CrossRef]

166. Breuer, C.K.; Shin'oka, T.; Galantowicz, M. A Pilot Study Investigating the Clinical Use of Tissue Engineered Vascular Grafts in Congenital Heart Surgery. Available online: https:/ / clinicaltrials.gov/ct2/show/NCT01034007 (accessed on 8 January 2022).

167. Shin'oka, T.; Matsumura, G.; Hibino, N.; Naito, Y.; Watanabe, M.; Konuma, T.; Sakamoto, T.; Nagatsu, M.; Kurosawa, H. Midterm Clinical Result of Tissue-Engineered Vascular Autografts Seeded with Autologous Bone Marrow Cells. J. Thorac. Cardiovasc. Surg. 2005, 129, 1330-1338. [CrossRef]

168. Cierpka, L.; de la Fuente, L. Use of a Lifeline Graft in the A-V Shunt Model. Available online: https://clinicaltrials.gov/ct2 / show / NCT00850252 (accessed on 8 January 2022).

169. Szczech, L. Evaluation of the Safety and Efficacy of a Vascular Prosthesis for Hemodialysis Access in Patients with ESRD. Available online: https: / / clinicaltrials.gov/ct2/show / NCT01744418 (accessed on 8 January 2022).

170. Lawson, J.H.; Glickman, M.H.; Ilzecki, M.; Jakimowicz, T.; Peden, E.K.; Pilgrim, A.J.; Prichard, H.L.; Guziewicz, M.; Przywara, S.; Szmidt, J.; et al. Bioengineered Human Acellular Vessels for Dialysis Access in Patients with End Stage Renal Disease: Two Phase 2 Single-Arm Trials. Lancet 2016, 387, 2026-2034. [CrossRef]

171. Szczech, L. Safety and Efficacy of a Vascular Prosthesis for Hemodialysis Access in Patients with End-Stage Renal Disease. Available online: https:/ / clinicaltrials.gov/ct2/show / NCT01840956 (accessed on 8 January 2022).

172. Morrison, J.J.; Mcmahon, J.; Dubose, J.J.; Scalea, T.M.; Lawson, J.H.; Rasmussen, T.E. Clinical Implementation of the Humacyte Human Acellular Vessel: Implications for Military and Civilian Trauma Care. Trauma Acute Care Surg. 2019, 87, 44-47. [CrossRef] [PubMed]

173. Szczech, L. Humacyte Human Acellular Vessel (HAV) in Patients with Vascular Trauma. Available online: https://clinicaltrials. gov/ct2/show / NCT03005418 (accessed on 8 January 2022).

174. Shin'oka, T.; Imai, Y.; Ikada, Y. Transplantation of a Tissue-Engineered Pulmonary Artery. Heart Vessels 2001, $344,532-533$. [CrossRef]

175. Kurobe, H.; Tara, S.; Maxfield, M.W.; Rocco, K.A.; Bagi, P.S.; Yi, T.; Udelsman, B.V.; Dean, E.W.; Khosravi, R.; Powell, H.M.; et al. Comparison of the Biological Equivalence of Two Methods for Isolating Bone Marrow Mononuclear Cells for Fabricating Tissue-Engineered Vascular Grafts. Tissue Eng.-Part C Methods 2015, 21, 597-604. [CrossRef]

176. Dahl, S.L.M.; Koh, J.; Prabhakar, V.; Niklason, L.E. Decellularized Native and Engineered Arterial Scaffolds for Transplantation. Cell Transplant. 2003, 12, 659-666. [CrossRef] 